\title{
Coreia do Sul, China e o processo de cafching-up: uma análise novo-desenvolvimentista
}

south Korea, china and the process of catching-up: a new-developmentalist analysis

Luiz callos Bresser-pereilia*

Elias Jabbou ${ }^{* *}$

Luiz Fernando de paula***

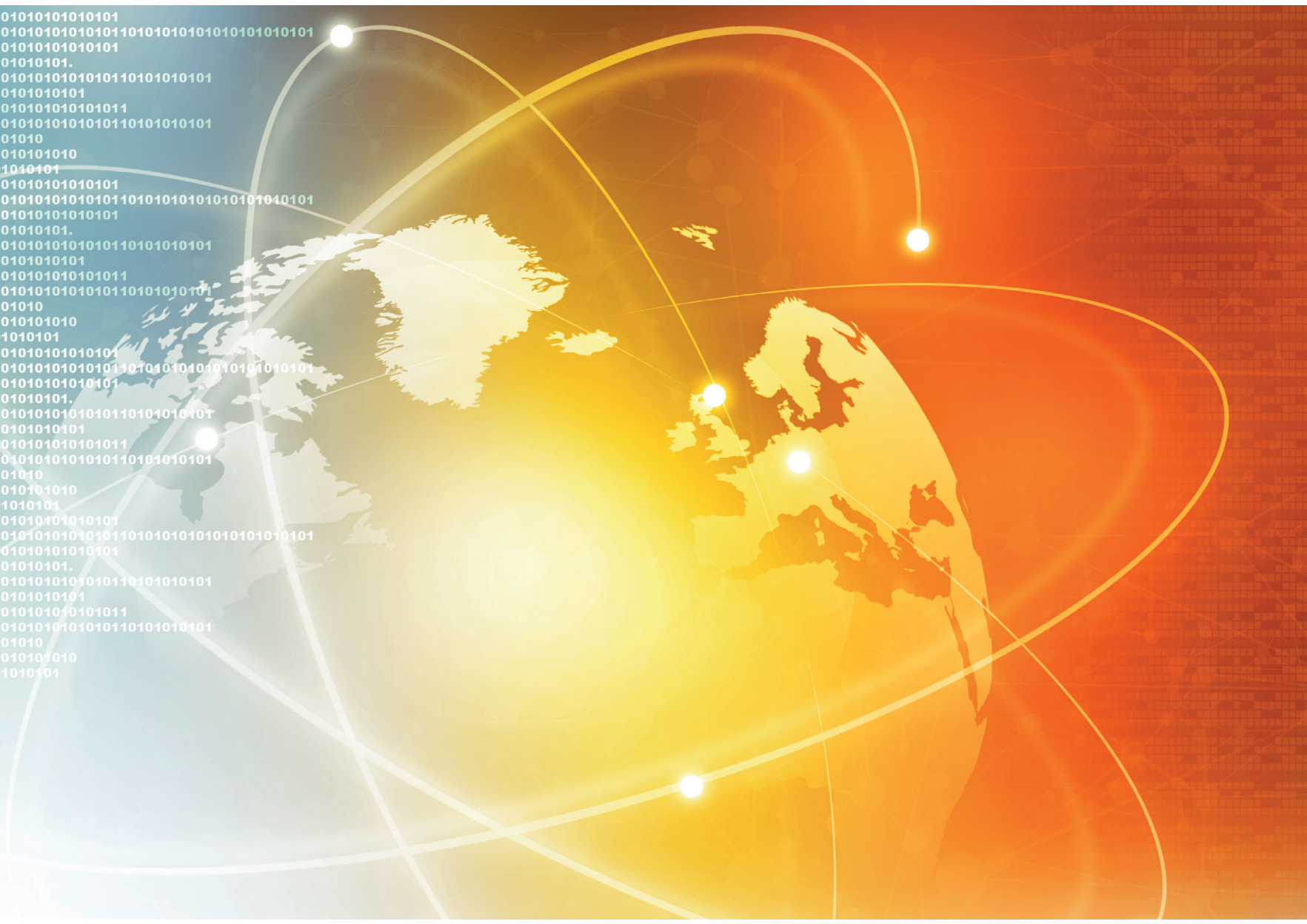




\section{RESUMO}

O objetivo deste artigo é analisar o processo de catching-up da Coreia do Sul e da China pós-reformas de 1978 com base em uma abordagem novo-desenvolvimentista que considere quatro fatores fundamentais: I) uma relação de complementaridade entre Estado e mercado como um processo dinâmico que se altera ao longo do tempo; 2) a necessária complementaridade entre política macroeconômica e política industrial; 3) o papel fundamental do Estado e dos bancos de desenvolvimento no enfrentamento do problema do "financiamento do desenvolvimento"; e, com destaque, 4) a centralidade da taxa de câmbio e do manejo na administração do balanço de pagamentos no processo de desenvolvimento desses dois países. A questão fundamental do artigo é em que medida o processo de catching-up nesses países pode ser entendido como a aplicação de uma estratégia novo-desenvolvimentista, levando em conta as devidas mediações históricas de cada país.

Palavras-chave: Leste Asiático; China; Catching-Up; Macroeconomia do desenvolvimento; Novo-desenvolvimentismo.

\section{ABSTRACT}

The objective of this paper is to analyze the catching-up process of Korea and the post-I978 Chinese reforms case, based on a new-developmentalist approach that considers four fundamental factors: I) a complementary relationship between state and market as a dynamic process that changes over time; 2) the necessary complementarity between macroeconomic policy and industrial policy; 3) the key role of the state and public banks in facing the problem of "funding the development"; and a special focus on 4) the centrality of exchange rate and of the payment administration balance for the development process in both countries. The fundamental question of this paper is to what extent the process of catching-up in these countries, especially the current Chinese case, can be understood as an application of a new-developmentalist strategy, taking in account the historical specificities of each country.

Keywords: East Asia; China, Catching-up; Developmental macroeconomics; New-developmentalist Strategy.

\section{INTRODUÇ̃̃OO}

É consenso entre economistas que a Coreia do Sul a partir dos anos 1960 e a China pós-reformas econômicas de 1978 são cases de sucesso de catching-up, ao contrário da América Latina, cujo processo de crescimento entrou em colapso desde a crise da dívida do México em I982. No quadro dessa crise os países latino-americanos adotam agendas em conformidade com o Consenso de Washington, sobretudo a 
abertura da conta financeira e a adoção de taxas de câmbio determinadas pelo mercado, desmontando assim o regime de política econômica desenvolvimentista que havia caracterizado sua industrialização nas quatro décadas anteriores, e entram em um processo de desindustrialização e (re)primarização de sua pauta de exportações.

A maioria dos trabalhos sobre o desenvolvimento econômico no Leste Asiático têm muitos pontos em comum, dentre os quais: I) a centralidade do papel do Estado na coordenação e elaboração de políticas industriais como meios de execução das respectivas estratégias nacionais de desenvolvimento; 2) a formação de conglomerados empresariais estatais ou privados em conexão com sistemas financeiros nacionais; 3) o enfrentamento ao problema crônico da restrição externa mediante estratégias de inserção externa via pautas de exportações, com crescente agregação de valor ao longo do tempo até se atingir a "fronteira tecnológica" ; 4) a formação de burocracias com alto grau de instrução comprometidas com o projeto nacional, trabalhando tanto na grande burocracia estatal quanto nos quadros administrativos dos conglomerados empresariais (chaebols, zaibatsus, keiretsus, grandes estatais chinesas etc.) (EVANS, 1993). A abordagem novo-desenvolvimentista, que um grupo de economistas vem construindo desde o início do século, é uma tentativa de explicar em termos teóricos ao mesmo tempo a experiência do Leste Asiático e a interrupção do processo de desenvolvimento econômico na América Latina a partir dos anos I980. Como explicar esse fato? Está ele relacionado com a manutenção por mais tempo da política desenvolvimentista naquele primeiro grupo de países e seu abandono radical no outro? Esse problema continua pouco desenvolvido na literatura. Tanto entre os estudos clássicos do desenvolvimentismo de tipo asiático quanto em muitos dos estudos mais recentes, pouca atenção foi dispensada à análise da política econômica no sentido de criar condições para um crescimento de longo prazo ${ }^{2}$.

A desmontagem dos mecanismos de neutralização da doença holandesa e a prática de juros elevados para atrair capitais externos e tentar crescer com poupança externa geram, como será visto no artigo, a tendência crônica de sobrevalorização cambial, que desestimula o investimento e estimula o consumo. Daí a importância da adoção de um nível de taxa de juros relativamente baixo e o manejo da taxa de câmbio para garantir oportunidades de investimento lucrativo para as empresas industriais, em vez de mantê-las prejudicadas por uma desvantagem competitiva de longo prazo. Uma tese central do novo-desenvolvimentismo é que uma taxa de câmbio apreciada no longo prazo é um fator determinante do baixo investimento privado na medida em

1 Nesse sentido, uma tese central percebida em Amsden (2004, p. 29) está no fato de que, "pela primeira vez na história, países 'atrasados' se industrializaram sem inovações próprias [...]. A industrialização tardia foi um caso de aprendizado puro".

2 Johnson (1982, p. 315-320), por exemplo, destaca quatro principais elementos explicativos do sucesso japonês: 1) existência de uma elite pequena de burocratas pronta para melhor atender às exigências do projeto nacional; 2) sistema político que garante liberdade de ação e escopo a essa burocracia; 3) perfeitos market-conforming methods, que geram formas racionais de intervenção do Estado na economia; 4) o papel-chave de instituições como o Ministério da Indústria e Comércio Exterior (MITI) no processo de coordenação e execução do próprio projeto nacional. Em nenhum momento de seu trabalho surge o papel da política econômica. 
que ela nega acesso à demanda às grandes empresas que utilizam a melhor tecnologia disponível. Ao mesmo tempo surge uma ampla literatura que mostra haver uma relação robusta de longo prazo entre taxa de câmbio competitiva e crescimento econômico (GALA, 2007; RODRIK, 2008; GUZMAN; OCAMPO; STIGLITZ, 20I8).

O objetivo do presente trabalho é analisar, de forma geral, o processo de catching-up da Coreia do Sul e o caso chinês pós-reformas de 1978 por meio de uma abordagem novo-desenvolvimentista que considere quatro fatores fundamentais: I) uma relação de complementaridade entre Estado e mercado como um processo dinâmico que se altera ao longo do tempo; 2) a necessária complementaridade entre política macroeconômica e política industrial;3) o papel fundamental do Estado e dos bancos de desenvolvimento no enfrentamento do problema do "financiamento do desenvolvimento"; e, com destaque, 4) a centralidade da taxa de câmbio e do manejo na administração do balanço de pagamentos no processo de desenvolvimento desses dois países.

Além desta introdução, o artigo está dividido em outras quatro seções. Na seção 2, discutimos as bases de uma estratégia novo-desenvolvimentista de catching-up e sua visão do processo de desenvolvimento econômico. $\mathrm{Na}$ seção 3, examinamos a aplicação da estratégia novo-desenvolvimentista relativa ao caso coreano, enquanto a seção 4 analisa a estratégia chinesa de desenvolvimento. Por fim, na seção 5 fazemos nossas considerações finais.

\section{A ESTRATÉGIA NOVO-DESENVOLVIMENTISTA DE CATCHING-UPE O FINANCIAMENTO DO DESENVOLVIMENTO}

A estratégia novo-desenvolvimentista supõe que os países que adotaram um regime de política econômica desenvolvimentista e realizaram o catching-up implementaram estratégias nacionais de desenvolvimento. Para Bresser-Pereira (20II), há dois problemas macroeconômicos fundamentais em países de renda média:

a) tendência de os salários crescerem abaixo do aumento da produtividade, em função da existência de uma oferta abundante de mão de obra em países em desenvolvimento;

b) tendência para a sobrevalorização da taxa de câmbio, que deriva de dois fatores estruturais: o problema da "doença holandesa" e uma apreciação cambial adicional causada pelos fluxos líquidos de capitais externos, estimulados pela política de crescimento com poupança externa.

Para se contrapor à primeira tendência, sugere-se o uso de políticas de renda, particularmente uma política de ganhos reais para o salário mínimo e a implantação de uma política que mantenha os salários crescendo em uma taxa próxima da produtividade e condizente com uma taxa de lucro satisfatória para a indústria (para evitar o fenômeno do profit squeeze). Quanto à segunda tendência, o novo-desenvolvimentismo preconiza uma política cambial baseada: a) no controle de capitais; b) na neutralização da doença holandesa; c) na rejeição de duas políticas habituais que implicam 
aumento da taxa de juros e entradas indesejadas de capitais no país. Essa política, que neutraliza a tendência de sobrevalorização cambial, deve ter como meta uma "taxa de câmbio de equilíbrio industrial” — isto é, aquela necessária para que empresas industriais, utilizando a tecnologia mais moderna, sejam competitivas internacionalmente (BRESSER-PEREIRA, 20II).

De forma mais detalhada, a tendência à sobreapreciação da taxa de câmbio resulta de dois fatores principais:

a) da doença holandesa, definida como

A crônica sobrevalorização da taxa de câmbio de um país causada pela exploração de recursos abundantes e baratos, que produz rendas ricardianas cuja produção comercial é compatível com uma taxa de câmbio claramente mais apreciada do que a taxa média de câmbio que torna economicamente viáveis os setores de bens comercializáveis que usam tecnologia de ponta (BRESSER-PEREIRA, 20II, p. I42).

Em outras palavras, a taxa de câmbio equilibra a conta-corrente, mas inviabiliza os setores de bens comercializáveis tecnologicamente mais sofisticados. A pressão da doença holandesa no sentido da sobrevalorização das moedas nacionais varia de acordo com a sua gravidade;

b) da política habitual de juros elevados para atrair capitais e tentar crescer com endividamento externo, e para usar a taxa de câmbio como âncora nominal no controle da inflação (BRESSER-PEREIRA, 20II). Contrariando o saber convencional, o novo-desenvolvimentismo é crítico da política de crescimento com poupança externa porque esta, ao apreciar a taxa de câmbio no longo prazo, tem o efeito inverso do pretendido: tira competitividade das empresas industriais e as desestimula a investir enquanto estimula o consumo.

Um fator acessório que pode contribuir para a sobreapreciação cambial é o populismo cambial; ao permitir que a taxa de câmbio se aprecie e que o país incorra em déficit em conta-corrente e acabe gastando mais do que arrecada, os salários e os rendimentos dos rentistas (juros, dividendos e aluguéis) aumentam "artificialmente", em função do barateamento da cesta de consumo, e a probabilidade de reeleição dos governantes aumenta.

A taxa de câmbio é vista como uma variável estratégica da política macroeconômica desenvolvimentista. Uma taxa de câmbio competitiva, além de estimular as exportações de maior valor agregado, estimula também o investimento para o mercado interno. A expansão puxada só pelo consumo tem efeitos limitados:

Consumo pode gerar crescimento econômico somente temporariamente, uma vez que seja política e economicamente possível induzir a redistribuição da renda em favor da classe trabalhadora. A existência de limites definidos para o aumento dos salários na renda nacional faz da expansão das exportações, no longo prazo, o agente do crescimento econômico (BRESSER-PEREIRA; OREIRO; MARCONI, 20I5, p. 29). 
De acordo com a estratégia novo-desenvolvimentista, não há conflito entre desenvolvimento do mercado interno e estratégia de crescimento baseada nas exportações, pois exportações aumentam o emprego, os salários e o consumo interno; ademais, estimulam a principal variável de demanda, que é o investimento. Uma questão central é que os produtores locais devem ter acesso à demanda interna e externa, e a variável-chave para conectá-los aos dois mercados é a taxa de câmbio competitiva. No caso das economias em desenvolvimento relativamente abertas da atualidade, fazê-las crescer voltando-as para o mercado interno enquanto a taxa de câmbio permanece apreciada é inviável. A demanda interna eventualmente existente em pouco tempo "vaza" para o exterior sob a forma de importações de bens manufaturados.

Em particular, uma nação deve adotar uma estratégia de crescimento puxado pelas exportações (export-led growth) por um breve período, isto é, em situações em que a taxa de crescimento corrente é insatisfatória, ou seja, está abaixo da taxa necessária para a realização do catching-up. Contudo, em uma situação de crescimento equilibrado, em que a taxa de investimento e de crescimento são razoavelmente satisfatórias, um país não precisa escolher entre uma estratégia export-led ou wage-led; o que ele precisa é de uma estratégia balanceada, na qual os salários cresçam à mesma taxa da produtividade e a razão lucro-salário permaneça constante, de modo que a taxa de lucro no longo prazo se mantenha em um nível satisfatório para estimular o empresário a investir.

Um aspecto importante dessa análise do desenvolvimento é que a taxa de câmbio afeta as elasticidades das funções exportações e importações. Como mostraram Prebisch e os modelos de crescimento restringido pelo balanço de pagamentos $\grave{a}$ la Thirlwall, os países produtores de bens de baixo valor agregado são constrangidos externamente em função do fato de a elasticidade-renda das importações ser maior do que a das exportações. Bresser-Pereira, Oreiro e Marconi (20I5), contudo, mostram que a elasticidade das exportações e a elasticidade das importações não são variáveis exógenas do modelo, determinadas somente pelo nível de conhecimento tecnológico do país, mas são também afetadas pela taxa de câmbio real. Assim, as elasticidades são variáveis endógenas que dependem da taxa de câmbio. Desse modo, uma taxa de câmbio real apreciada afeta negativamente a estrutura produtiva e produz um processo perverso de especialização na produção de bens intensivos em recursos naturais e de inibição de investimento em setores de bens comercializáveis, causando — via desindustrialização - um baixo crescimento econômico. Alternativamente, uma taxa de câmbio real competitiva, flutuando em torno do equilíbrio industrial, pode ter um efeito inverso, afetando positivamente a estrutura produtiva, contribuindo para produzir um processo virtuoso de diversificação produtiva (inclusive em direção a bens de maior valor agregado) e dando origem a um crescimento econômico maior.

Ao contrário do que supõe a teoria econômica convencional, a taxa de câmbio não é uma variável endógena; ela não é "o que tem de ser", aquilo que o mercado determina. Por intermédio de uma política cambial que envolva elementos estruturais 
como a rejeição de determinadas políticas habituais nos países em desenvolvimento e a neutralização da doença holandesa, é possível mantê-la competitiva. Uma política macroeconômica que tem por objetivo uma taxa de câmbio competitiva é capaz de gradualmente elevar a taxa de poupança, uma vez que os lucros empresariais crescem, em função do maior dinamismo das vendas tanto para o mercado interno quanto para o externo. Dada a maior propensão a poupar das empresas industriais, a poupança doméstica agregada tende a se elevar por conta do maior investimento (que é o que gera renda na economia). Logo, a taxa de poupança depende da taxa de investimento, que depende da existência de oportunidades de lucro, que, por sua vez, resultam das oportunidades de exportações manufatureiras que só existem se a taxa de câmbio não estiver sobrevalorizada e, portanto, as empresas tecnologicamente competentes tiverem acesso à demanda tanto interna quanto externa. Por outro lado, a teoria novo-desenvolvimentista defende a rejeição dos déficits em conta-corrente, que, ao implicarem entradas adicionais de capitais externos, apreciam a taxa de câmbio e tornam não competitivas as boas empresas, ao mesmo tempo que estimulam o consumo. Isso só não acontece nos momentos de "milagre" ou forte crescimento econômico, porque nesses momentos as grandes oportunidades de investimento causam a queda da taxa de substituição da poupança interna pela externa (BRESSER-PEREIRA; GALA, 2008). Bresser-Pereira (2009) distingue duas taxas de câmbio: a taxa de câmbio de equilíbrio corrente, isto é, que equilibra intertemporalmente a conta-corrente de um país, sendo, portanto, a taxa para a qual o mercado converge; e a que denomina taxa de câmbio de equilíbrio industrial, que é aquela que permite a produção (e exportação) de bens comercializáveis no país sem necessidade de impostos e subsídios, i.e., é a taxa de câmbio que na média permite às empresas que usam a tecnologia no estado da arte serem lucrativas e competitivas ${ }^{3}$. Quanto maior a divergência entre as duas taxas, mais grave será a doença holandesa. Contudo, em função da pressão dos afluxos de capitais externos, a taxa de câmbio continua a se apreciar ainda mais, contribuindo para gerar déficits em conta-corrente. À medida que o déficit em conta-corrente aumenta, sob a pressão da política de crescimento com poupança externa e do populismo cambial, acaba-se minando a confiança dos investidores e credores internacionais, abrindo a possibilidade de uma crise do balanço de pagamentos, causando uma abrupta e aguda depreciação cambial.

3 Para o desenvolvimento de uma metodologia para estimar a taxa de câmbio de equilíbrio industrial, ver Marconi (2012). 


\section{De acordo com a estratégia novo-}

\section{desenvolvimentista, não há conflito entre} desenvolvimento do mercado interno e estratégia de crescimento baseada nas exportações, pois exportações aumentam o emprego, os salários e o consumo interno; ademais, estimulam a principal variável de demanda, que é o investimento. Uma questão central é que os produtores locais devem ter acesso à demanda interna e externa, e a variável-chave para conectá-los aos dois mercados é a taxa de câmbio competitiva

Bresser-Pereira assinala que países de renda média que realizaram seu catch-up neutralizaram de alguma forma a tendência de sobrevalorização da taxa de câmbio. Na prática, vários países neutralizaram a doença holandesa de diversas formas, com uso de taxas múltiplas de câmbio, tarifas de importação e subsídios às exportações que implicavam um imposto disfarçado sobre as commodities. Bresser-Pereira (2009, cap. 5) sugere especificamente a neutralização da doença holandesa por meio de um imposto sobre a venda dos bens que lhe dão origem (o imposto deve corresponder à diferença entre a taxa de câmbio de equilíbrio corrente e a taxa de câmbio de equilíbrio industrial) e a criação de um fundo internacional com as receitas derivadas desse imposto, para evitar que o ingresso dessas receitas revalorize a taxa de câmbio, de modo a tornar as duas taxas de câmbio de equilíbrio razoavelmente próximas.

Nesse sentido, a ampliação do comércio exterior ocorrerá sob o acicate de instituições que garantam a realização de uma política cambial que ligue as empresas nacionais ao mercado interno e da ampliação da competitividade das empresas nacionais nos mercados externos. Para isso, a implantação de um imposto sobre a exportação de commodities, a rejeição de políticas e práticas que elevam a taxa de juros e o gerenciamento de mecanismos de controle sobre a entrada e saída de capitais são elementos básicos da política cambial proposta.

Cabe assinalar que, segundo a estratégia novo-desenvolvimentista, a política industrial tem um papel estratégico e complementar, não podendo ser substituta de uma política macroeconômica adequada, baseada no equilíbrio fiscal, taxas de juros moderadas, taxa de câmbio competitiva e taxa de lucro satisfatória para as empre- 
sas produtoras de bens comercializáveis não commodities. Ademais, sustenta que deve haver uma articulação entre política cambial e política fiscal, no sentido de que esta deve estar ciclicamente equilibrada para contrapor-se aos efeitos expansionistas de longo prazo de uma taxa de câmbio competitiva.

Por fim, deve-se agregar à visão novo-desenvolvimentista a questão do financiamento do desenvolvimento. O novo-desenvolvimentismo rejeita o financiamento externo, que só é benéfico em situações particulares, quando a alta taxa de substituição da poupança interna pela externa cai, mas naturalmente considera essencial o financiamento externo. Keynes (1937), em um debate logo após a publicação de sua teoria geral em 1936, fez uma importante distinção entre poupança e financiamento: o que o empresário precisa para concretizar suas decisões de investimento é ter acesso à liquidez, provida pelo setor bancário ou pela renúncia à liquidez por parte dos agentes, e não de poupança prévia. Para tanto, é necessário haver um setor bancário com capacidade de criar poder de compra novo via crédito. Poupança ex post é gerada com base nas decisões autônomas de investimento, como resultado do processo multiplicador de renda (em que parte é consumida e parte é poupada). Essa poupança ex post, se bem canalizada para o sistema financeiro, pode contribuir para consolidar a dívida de curto prazo das firmas investidoras em uma estrutura de dívida de longo prazo compatível com a maturidade de seus ativos de longo prazo, reduzindo a tendência à fragilidade financeira típica de economias em crescimento. Nesse sentido, um sistema financeiro funcional ao desenvolvimento econômico é aquele capaz de prover financiamento (finance) que permita aos empresários fazer gastos com investimentos e que canalize poupança para, direta ou indiretamente, fundar suas dívidas (funding). As experiências do século XX mostram que em todos os países que realizaram seu catching-up houve alguma forma uma intervenção do Estado na questão do financiamento do investimento, seja diretamente, via bancos públicos, ou indiretamente, com linhas de crédito subsidiadas operadas por bancos privados. Não há razão para supor que os mecanismos de financiamento e sobretudo de funding surjam espontaneamente pelo simples funcionamento do mercado (PAULA, 2013).

Note que a abordagem acima referida é compatível com a visão novo-desenvolvimentista. Ela incorpora o mecanismo keynesiano segundo o qual a poupança é resultado das decisões de investimento, mas no caso de economias em desenvolvimento as exportações líquidas têm um papel estratégico em sustentar taxas de lucro mais elevadas, sobretudo durante a fase de catching-up. Contudo, há necessidade de cada país contar com um sistema financeiro que seja funcional ao crescimento econômico, no sentido de prover financiamento no volume e maturidade adequados para a realização das decisões de investimento.

Como veremos a seguir, as economias da Coreia do Sul e da China não só adotaram políticas de administração de seu balanço de pagamentos e uma estratégia export-led growth para a realização de seu catching-up como também enfrentaram o problema da restrição financeira ao processo de desenvolvimento. Evidentemente, 
contudo, devem-se considerar as especificidades de cada caso, inclusive no que se refere ao momento de realização do processo de catching-up: dos anos 1970 até meados dos I990, no caso coreano, e a partir dos anos I980, no caso da China. Com as devidas adaptações, há alguma evidência de que esses países adotaram uma estratégia de desenvolvimento próxima ao novo-desenvolvimentismo.

\section{O NOVO-DESENVOLVIMENTISMO E O CASO DA COREIA DO SUL}

Não é fato novo atribuir à Coreia do Sul e China trajetórias de sucesso na realização do seu processo de catching-up e explicá-las por uma série de políticas econômicas que incluíram: a) políticas domésticas com o objetivo de formar grandes conglomerados; b) estratégias agressivas de desenvolvimento e formação — além de proteção - do mercado interno; c) uso do comércio internacional como variável estratégica que facilitou a internalização de tecnologias de ponta e exportações de elevado valor agregado per capita; d) grandes superávits comerciais com os Estados Unidos, que permitiram superávits em conta-corrente ; e) elevado investimento em educação e tecnologia; f) amplo uso de políticas industriais estratégicas (JOHNSON, I982; AMSDEN, I989).

O novo-desenvolvimentismo acrescenta a essas variáveis a política macroeconômica, que foi novo-desenvolvimentista porque manteve relativamente equilibradas as duas contas macroeconômicas (a fiscal e a externa) e porque usou não apenas de política monetária e política fiscal, mas também de política cambial para manter certos os cinco preços macroeconômicos (taxa de lucro, taxa de juros, taxa de câmbio, taxa de salários e taxa de inflação) e, assim, garantir às empresas locais condições de competição iguais às das empresas dos demais países. Esse conjunto de políticas microeconômicas e macroeconômicas constituiu-se em modelo para os demais países do Leste Asiático, que se deslocaram em formação como os gansos voadores, em contraste com o baixo crescimento das economias latino-americanas (PALMA, 2009).

\section{I. Coreia do Sul: um impressionante caso de export-led growth}

O crescimento export-led da Coreia do Sul durante todo o período de catching-up confirma a tese incorporada na estratégia novo-desenvolvimentista sobre o papel das exportações. Sua trajetória de crescimento econômico é impressionante, com média de 9,6\% entre os anos de I963 e I995, conforme demonstra o gráfico I.

4 Cabe ressaltar que esses países aproveitaram-se de um período de câmbio fixo atrelado ao dólar (regime de Bretton Woods) e das condições políticas favoráveis em função da Guerra Fria. A questão, nesse caso, não foi a oportunidade em si, mas o fato de se ter aproveitado esse momento para promover um vigoroso catching-up. 
Gráfico 1 - Crescimento do PIB real (\% a.a.) - Coreia do Sul, 1960-2018

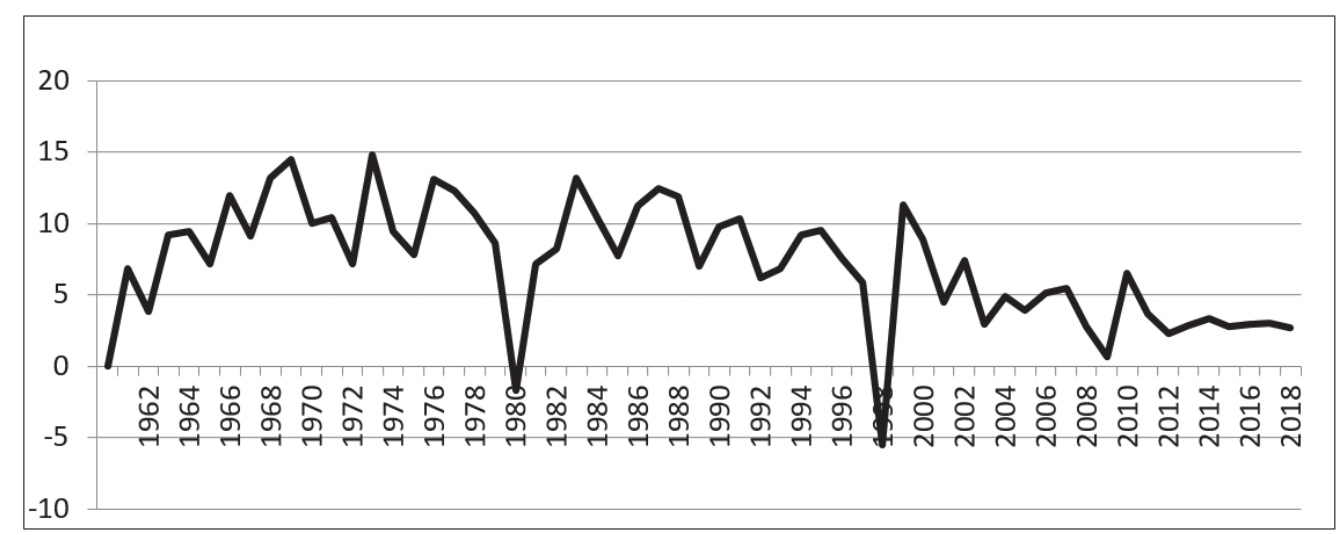

Fonte: World Bank.

No caso coreano, essa dinâmica exportadora contou com o suporte da combinação de política econômica pró-crescimento com políticas industriais setoriais e de caráter crescentemente intensivo em capital. Como mostra o gráfico 2, a taxa de investimento da Coreia (variável-chave para analisar processos de catching-up) teve um crescimento vertiginoso - passa de II\% na primeira metade da década de 1960 para mais de $20 \%$ do PIB a partir de meados dessa década, vindo a alcançar mais de $30 \%$ a partir do início da década de 1980 e chegando a atingir mais de $35 \%$ na primeira década de 1990.

Gráfico 2 - Formação bruta de capital fixo/PIB (\%) — Coreia do Sul, 1960-2017

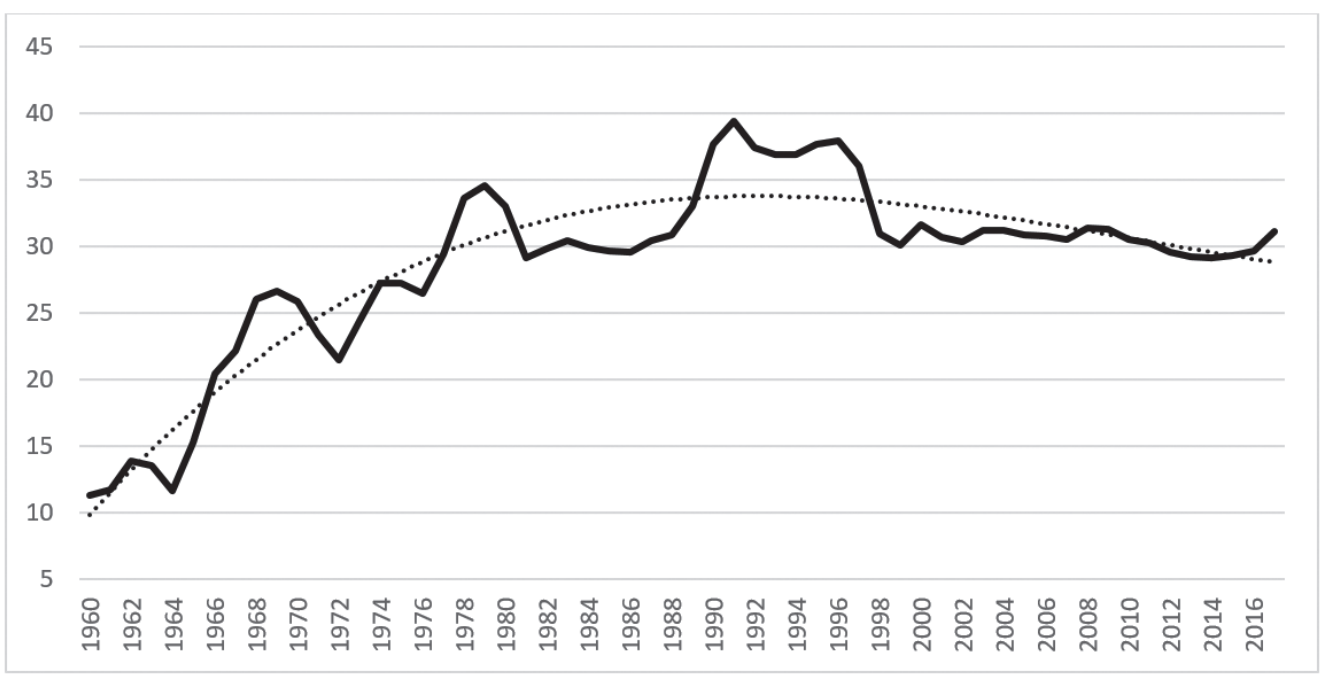

Fonte: World Bank.

Já no que se refere à renda per capita, o crescimento é igualmente vigoroso: de apenas U\$ I58,24 em I960, um nível então semelhante ao do Haiti, para US\$ 830,70 em 1976, passando para US\$2.803,37 em I986; a partir daí, o crescimento é exponen- 
cial, alcançando US\$ I3.I37,9I em I996, US\$20.888,38 em 2006 e US\$ 29.742,84 em 2017 (gráfico 3). Por detrás dessa tendência observou-se uma rápida e intensa mudança na estrutura produtiva do país, de uma economia essencialmente agrária para uma economia industrial: a participação do setor manufatureiro (incluindo mineração) cresceu de I2\% do PNB em I954-I956 para 30\% em I977-I98I, enquanto o setor agrícola (incluindo pesca) caiu de 44,6\% para I8,3\% no mesmo período (KIM, I99I). De fato, a Coreia do Sul no início dos anos 1960 era um país bastante atrasado economicamente e pobre em recursos naturais (com apenas 30\% das terras cultiváveis). Numa perspectiva histórica, sua fase inicial de desenvolvimento pode ser dividida em dois períodos: substituição de importações (I954-I960) e orientação para fora (I96I-I979).

\section{Gráfico 3 - PIB per capita (em US\$ correntes) — Coreia do Sul, 1960-2017}

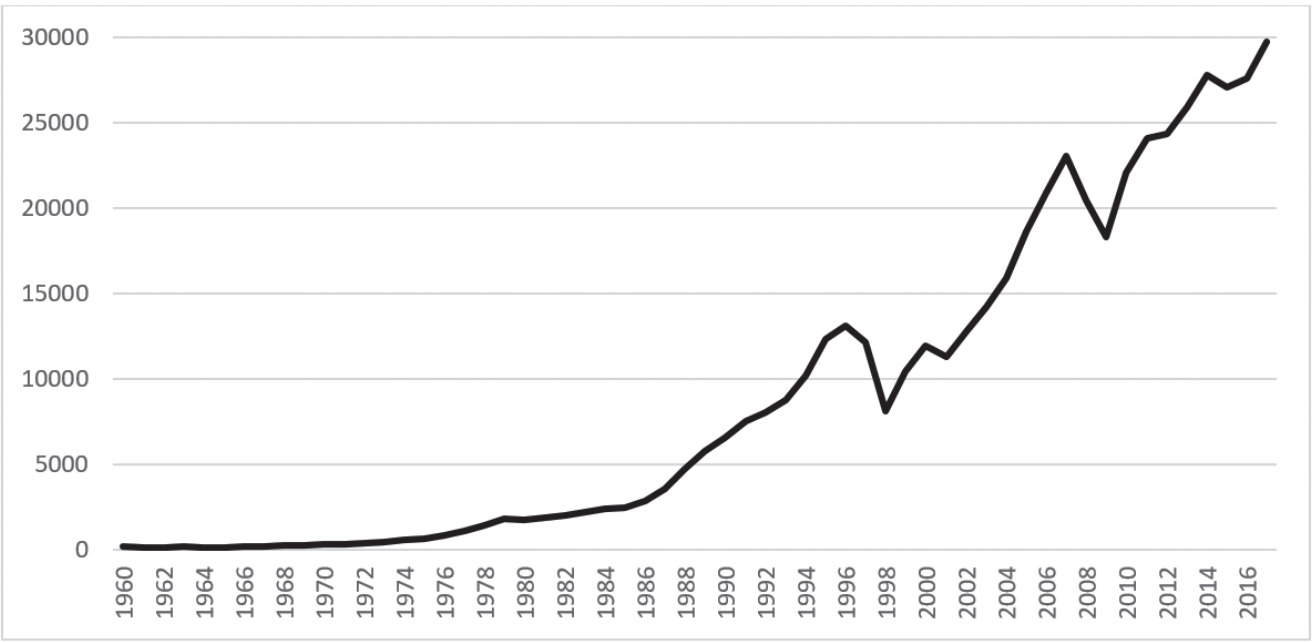

Fonte: World Bank.

O processo de desenvolvimento da Coreia do Sul pode ser visto como o mais impressionante e rico processo de catching-up do último quarto do século XX, pela rapidez com que foi realizado, acompanhado de uma profunda mudança estrutural. É difícil atribuir a um único fator a causa do sucesso sul-coreano. A estratégia sul-coreana de catching-up incluiu em linhas gerais: I) como no caso japonês, precoce concentração e centralização do capital sob a forma de grandes conglomerados ou chaebols; 2) forte participação do governo nos anos 1960 e 1970 no desenvolvimento de infraestrutura econômica (estradas, portos, eletricidade, irrigação, transporte, comunicação etc.), por meio de fundos públicos e empresas estatais ; 3) combinação pragmática - e em momentos-chave, como entre 1957 e I960 e no início da década de 1980 - de políticas macroeconômicas competentes para fins de estabilização de preços (tal como no Japão na década de 1950) com políticas industriais voltadas para substituir importações, uti-

5 A participação estatal foi de cerca de 40\% do total do investimento em 1963-1979, conforme Kim (1991, tab. 3.1). 
lizando-se de restrições a importações e elevação de tarifas alfandegárias; 4) estatização do sistema financeiro e utilização do sistema de bancos comerciais e do Banco de Desenvolvimento da Coreia para alavancar setores industriais selecionados, além da criação do Fundo Nacional de Investimento (I973) e do Banco de Exportações e Importações da Coreia (1976), objetivando financiar as exportações com taxa de juros abaixo do preço de mercado (COUTINHO, I999, p. 353); 5) unificação cambial (I96I) e sucessivas minidesvalorizações da taxa de câmbio; 6) ampla gama de incentivos governamentais — subsídios e garantias de créditos, proteção contra importações, benefícios fiscais - e uso de empréstimos externos com alguma funcionalidade para o financiamento do desenvolvimento (ALDRIGHI, I997, p. I42); 7) políticas industriais ativas mediadas por abrangentes planos quinquenais; 8) burocracia estatal capaz de escolher seu staff entre os mais talentosos membros das mais conceituadas universidades e centralizar sua atuação em instituições como o Departamento de Planejamento Econômico (EVANS, I993, p. IIO).

O gráfico 4 atesta a existência de uma dinâmica de crescimento voltada às exportações, notadamente em concomitância com um continuado esforço de acumulação de capital, em uma estratégia de desenvolvimento que combinou um vigoroso processo de substituição de importações com um forte empuxo dinâmico das exportações (AMSDEN, 1989). De fato, a relação exportações/PIB cresceu vigorosamente: de $2,62 \%$ em I960 para mais de $20 \%$ a partir de I973, crescendo com oscilações até atingir mais de $40 \%$ após 2007 , ainda que tenha se reduzido mais recentemente. Outro indicador desse dinamismo está na evolução rápida de suas reservas cambiais, que saem de US\$20,4 bilhões em 1997 para US\$ 392,5 bilhões em outubro de 20I8. O roteiro dos consecutivos planos quinquenais indica isso; desde o esforço de industrialização pela indústria leve em têxteis e confecções (Io Plano Quinquenal, I962-1967) até o final da era coreana de substituição de importações (implantação da indústria mecânica pesada; $5^{\circ}$ Plano Quinquenal, I977-I98I).

\section{Gráfico 4 - Relação exportações/PIB (\%) - Coreia do Sul, 1960-2017}

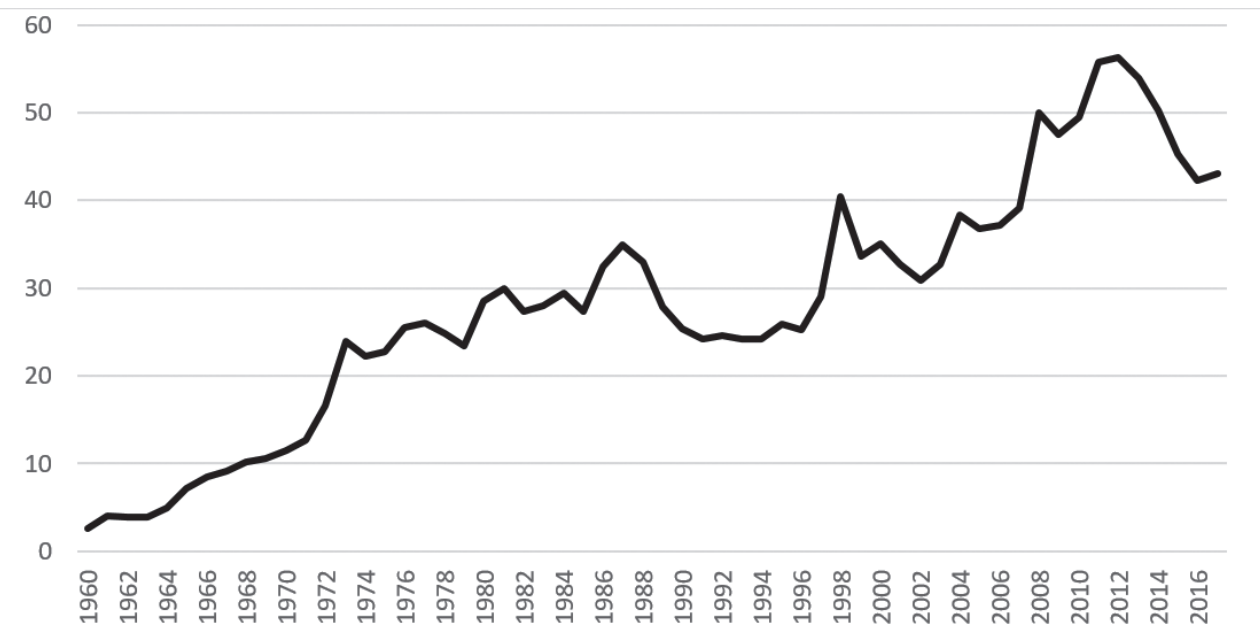


Além de um engenhoso processo de administração da balança comercial, em concomitância com subsídios creditícios, a desvalorização da taxa de câmbio — variável-chave do ponto de vista da competitividade externa - favoreceu o dinamismo exportador da Coreia do Sul: após a valorização real do câmbio em I964-I97I, observou-se uma tendência geral de desvalorização real da moeda, até o início dos anos 2000, quando se inicia um processo de valorização gradual da taxa de câmbio real efetiva (gráfico 5).
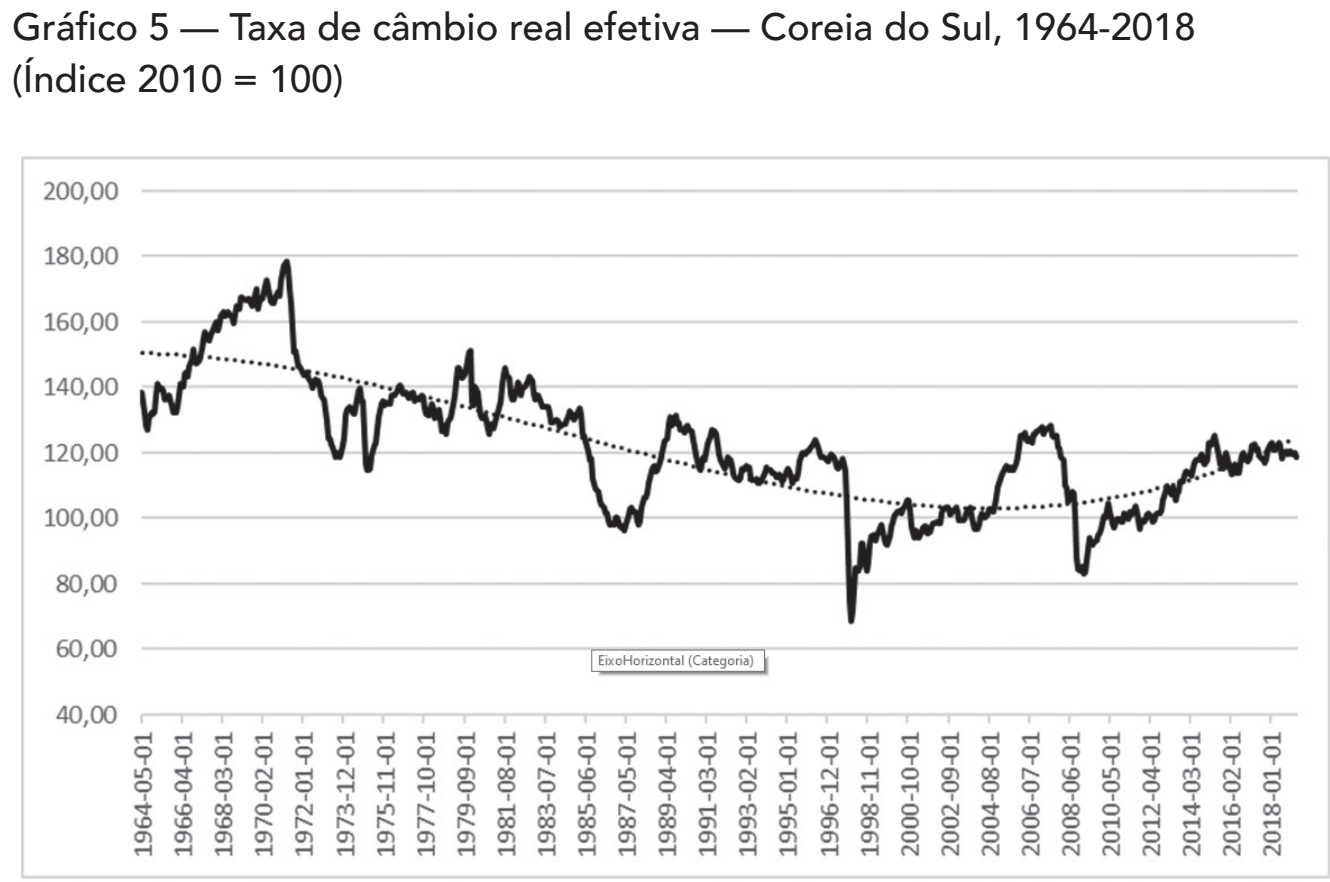

Fonte: Federal Reserve Economic Data.

É evidente que o governo sul-coreano não somente executou políticas cambiais ativas, mas também criou um aparato institucional de incentivo às exportações, principalmente a partir da década de 1960 , um sistema de proteção do mercado interno (via tarifas de importações) e políticas voltadas para o aumento da complexidade das próprias cadeias produtivas do país, que se refletem até hoje sobre o nível de valor agregado das exportações. Esse "sistema planificado de comércio exterior", ao se combinar com políticas industriais e de substituição de importações (neste caso, em particular nos anos 1960), foi crescentemente beneficiado por políticas setoriais voltadas a cadeias produtivas com capacidade de competitividade no mercado internacional. O modelo desenvolvimentista coreano, que Kim (I99I, p. Io) denomina "neomercantilista", pode ser definido como um círculo virtuoso conforme o qual o Estado provê as condições institucionais para seu desenvolvimento ou, mais amplamente, as condições gerais para a acumulação de capital. Segundo Kim:

As intervenções estatais podem ser fundamentais para manter o círculo virtuoso do crescimento em movimento. Se, por exemplo, as exportações tiver- 
em dificuldades, o governo poderá introduzir medidas para estimular as demandas por exportação. Tais políticas incluem desvalorização da taxa de câmbio, subsídios à exportação ou outras formas de incentivo às exportações. Se o setor exportador começar a perder vantagem competitiva nos mercados internacionais, o governo poderá recorrer a políticas fiscais ou monetárias para conceder incentivos especiais ou, até mesmo, controlar diretamente setores ou empresas específicos. As importações seriam limitadas a setores complementares ao desenvolvimento do setor de exportação. Políticas comerciais de proteção seriam necessárias para proteger a posição da balança de pagamentos do país. (I99I, p. I2, tradução e grifos nossos)

Parte desse sistema de comércio exterior, a proteção no mercado interno às indústrias nascentes, foi fundamental na criação de vantagens competitivas nos mercados internacionais (ALDRIGHI, I997, p. I59). Ao lado disso, o Estado proveu concessões de todo tipo às indústrias exportadoras, sendo seletivas em matéria de proteção às exportações: a instalação de novas cadeias produtivas ou a ampliação das já existentes só se justificaria dentro de uma estratégia que contemplasse a conquista de mercados externos. Dentre os principais estímulos às exportações, além de taxas de câmbio convidativas, podemos elencar: I) subsídios diretos; 2) taxas de juros abaixo das praticadas no mercado para empresas exportadoras ; 3 ) restrições quantitativas a importações de capital ${ }^{7}$.

Do ponto de vista da política de crédito e financiamento, um dos mais importantes instrumentos para implementação de uma política setorial orientada para o desenvolvimento industrial foi o controle estatal sobre a alocação de crédito. Já desde as reformas financeiras de I964-I965, a Coreia desenvolveu um "sistema financeiro baseado no crédito bancário". A relação entre crédito doméstico ao setor privado e PIB cresceu acentuadamente de 56,3\% em 1960 para I29,3\% em I972. De fato, as instituições bancárias, que eram direta ou indiretamente controladas pelo governo, proveram a maior parte do financiamento ao investimento na indústria. De particular importância era um tipo de empréstimo chamado de policy loans, que tinham taxas de juros excepcionalmente baixas e termos lenientes de pagamento, e eram administrados por bancos públicos de desenvolvimento, sendo disponíveis primariamente para propósitos de financiamento das exportações e de indústrias consideradas chave. Um órgão ligado ao Ministério da Fazenda, o Departamento de Planejamento Econômico, definia os critérios e condições de acesso aos policy loans pelas instituições bancárias, sendo normalmente direcionadas para dar suporte a setores priorizados pelo gover-

6 De acordo com Kim (1991, p. 22) as taxas de juros para exportações eram, em abril de 1962, de $12,7 \%$, enquanto as taxas e juros comerciais foram de 16,73\%. Essa dinâmica foi recorrente e até aprofundada: em janeiro de 1980 os juros aplicados aos exportadores eram de 12\%, enquanto a taxa comercial chegou a $25 \%$. Segundo o autor, os subsídios creditícios às exportações eram uma das medidas mais importantes de incentivo a essa atividade.

7 Para um aprofundamento sobre os incentivos às exportações e restrições às importações, ver Kim (1991) e Aldrighi (1997). 
Pode-se dizer que o final do século $X X$

foi marcado pela confluência de um

caso de extremo sucesso de catching-

up, iniciado nas últimas quatro décadas

do referido século (Coreia do Sul), com

o início e consolidação de um dos casos

mais impressionantes de desenvolvimento

robusto e continuado da história

(República Popular da China)

no. Um grupo de bancos públicos de desenvolvimento foi instituído no país, destacando-se o Korea Development Bank (I5\% do total de empréstimos em I984) e o Korea Export-Import Bank, especializado no crédito de médio e longo prazo para transações do comércio exterior, em particular exportações (KIM, I99I).

Um fator importante da estratégia coreana foi o mix entre endividamento externo e investimentos diretos estrangeiros (IDEs). Podemos classificar a utilização de tais instrumentos como algo coerente com uma estratégia de desenvolvimento que combinou, no curto prazo, um certo grau de escassez de recursos com a almejada soberania econômica em face de um mundo em transformação, incluindo a aproximação entre Estados Unidos e China (197I) e seus efeitos na dinâmica de crescimento sul-coreana (ALDRIGHI, 1997, p. I59). O endividamento externo da Coreia do Sul nos anos 1970 serviu de funding com fins produtivos específicos (e não para aumento consumo doméstico): financiar compra de pacotes tecnológicos inteiros pelo setor privado e investimentos de longo prazo, como em infraestrutura econômica. Apesar de a Coreia do Sul no início da década de I980 contar com uma elevada dívida externa, cabe salientar que a taxa de crescimento nos anos 1970 foi espetacular, ensejando grandes oportunidades de investimento associado ao crescimento rápido, em um contexto de alta propensão marginal a poupar; em consequência, a taxa de substituição da poupança interna pela externa foi baixa. Assim, conforme ensina a teoria novo-desenvolvimentista, nesse período a poupança externa se somou à interna em vez de substituí-la, como acontece nos períodos normais. De fato, o endividamento externo dos anos I970 deu ensejo (dada a implantação da indústria mecânica pesada e da indústria química) a uma elevação indireta da taxa de poupança nacional derivada do rápido crescimento no nível da renda e da produção: a taxa de poupança em relação ao PIB cresceu de 8\% em I965 para 38\% em I989; os IDEs nunca foram elemento fundamental de adensamento produtivo doméstico (ALDRIGHI, I997, p. I68-I69). 
Além disso, cabe assinalar: I) a poupança externa (incluindo aí as ajudas unilaterais estadunidenses) nunca passou dos I0\% dos fundos para investimentos em capital fixo no país; 2) sua experiência de endividamento externo distingue-se pela participação menor de dívidas do setor público, evitando que os ajustes onerem as finanças governamentais (como foi o caso brasileiro nos anos I980).

Também é importante a forma particular do comportamento do balanço de pagamentos do país. O gráfico 6 demonstra um comportamento temporal em que déficits crônicos ocorreram notadamente entre os anos de I976 e I985 - notadamente fruto de endividamento externo e dos choques do petróleo de 1973 e I979 —, porém com tendência a superávits que se mantém desde 1997, tornando-se elemento fundamental explicado pelos ganhos crescentes de valor agregado de suas exportações.

\section{Gráfico 6 - Balanço de pagamentos (\% do PIB) - Coreia do Sul, 1976-2018}

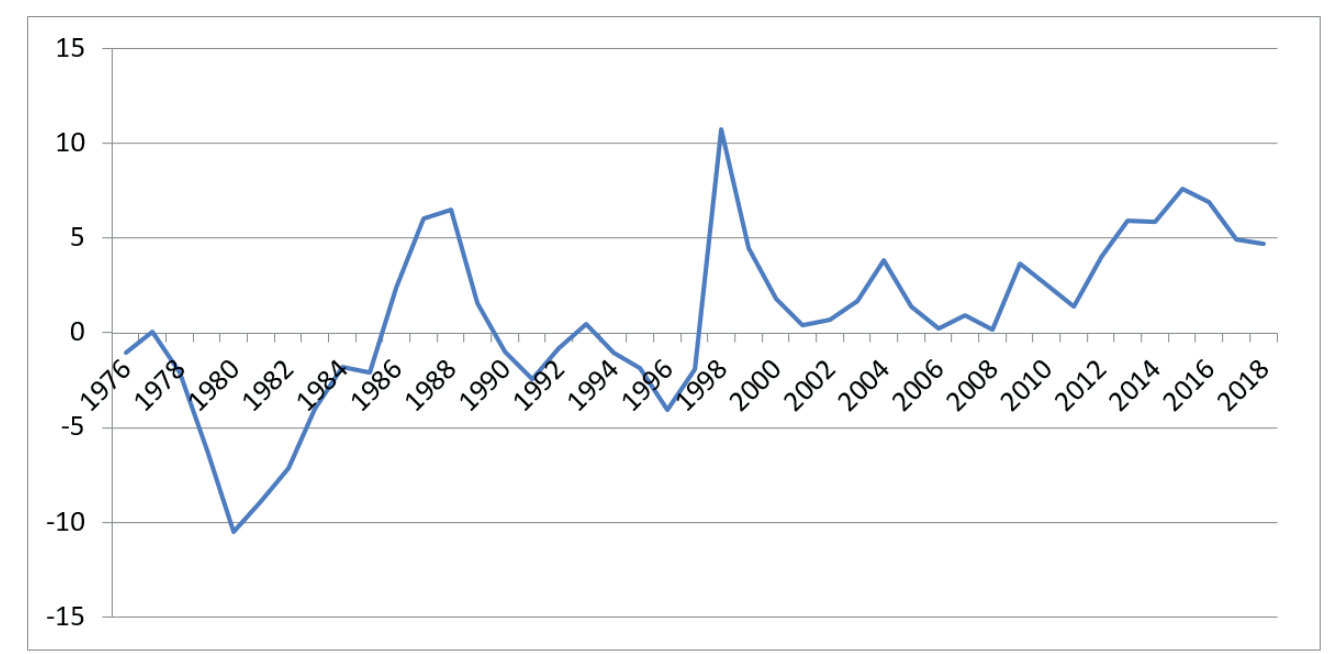

Fonte: World Bank.

Outra dimensão da estratégia sul-coreana é a relação entre salários e produtividade do trabalho. Essa relação deve servir tanto a uma virtuosa distribuição funcional da renda quanto a taxas de lucros atrativas para o investimento privado. Nesse aspecto pode-se dizer que a Coreia do Sul passou pelo "modelo Lewis", pois a abundância da mão-de-obra foi fundamental para a acumulação de capital na medida em que foi responsável por manter a taxa de salários praticamente inalterada entre 1958 e I967 (KIM, I99I, p. 44). Em meados dos anos 2000 o país encontrava-se em estágio intermediário entre o nível de salários praticados nos EUA e Japão e os praticados no restante do Sudeste Asiático (GUARINI; RABELLOTTI, 2006, p. 7). A tabela I mostra que o crescimento da taxa real esteve sempre abaixo da produtividade do trabalho de I967 a I975, sendo que a partir de 1976 começa a se inverter tal tendência. Expressivos aumentos salariais podem ser observados no final da década de 1970, momento em que novas leis e regulamentos sobre o trabalho foram elaborados e postos em prática — fruto também da crescente sindicalização dos trabalhadores urbanos. 
Tabela 1 - Salários reais e produtividade do trabalho na indústria - Coreia do Sul, 1967-1978

\begin{tabular}{r|r|r|r|r}
\hline \multirow{2}{*}{ Ano } & \multicolumn{2}{|c|}{ Taxa de crescimento } & \multicolumn{2}{c}{ Índice (1966 = 100) } \\
\cline { 2 - 5 } & $\begin{array}{c}\text { Taxa real } \\
\text { de salário }\end{array}$ & $\begin{array}{c}\text { Produtividade } \\
\text { do trabalho }\end{array}$ & $\begin{array}{c}\text { Taxa real } \\
\text { de salário }\end{array}$ & $\begin{array}{c}\text { Produtividade do } \\
\text { trabalho }\end{array}$ \\
\hline $\mathbf{1 9 6 7}$ & 10,4 & 17,7 & 110,4 & 117,7 \\
\hline $\mathbf{1 9 6 8}$ & 13,9 & 19,8 & 125,7 & 141,1 \\
\hline $\mathbf{1 9 6 9}$ & 21,7 & 26,5 & 153,1 & 178,4 \\
\hline $\mathbf{1 9 7 0}$ & 11,5 & 12,6 & 170,6 & 200,8 \\
\hline $\mathbf{1 9 7 1}$ & 2,4 & 9,8 & 174,7 & 220,5 \\
\hline $\mathbf{1 9 7 2}$ & 1,9 & 9,0 & 178,0 & 240,4 \\
\hline $\mathbf{1 9 7 3}$ & 14,4 & 10,4 & 203,7 & 265,4 \\
\hline $\mathbf{1 9 7 4}$ & 8,9 & 11,2 & 221,8 & 295,1 \\
\hline $\mathbf{1 9 7 5}$ & 1,5 & 11,6 & 225,1 & 329,3 \\
\hline $\mathbf{1 9 7 6}$ & 17,7 & 11,9 & 265,0 & 368,5 \\
\hline $\mathbf{1 9 7 7}$ & 20,6 & 3,9 & 319,6 & 382,9 \\
\hline $\mathbf{1 9 7 8}$ & 17,1 & 11,5 & 374,3 & 426,9 \\
\hline
\end{tabular}

Fonte: Kim, 1991.

\section{CHINA: O NOVO-DESENVOLVIMENTISMO COM DIMENSÕES CONTINENTAIS}

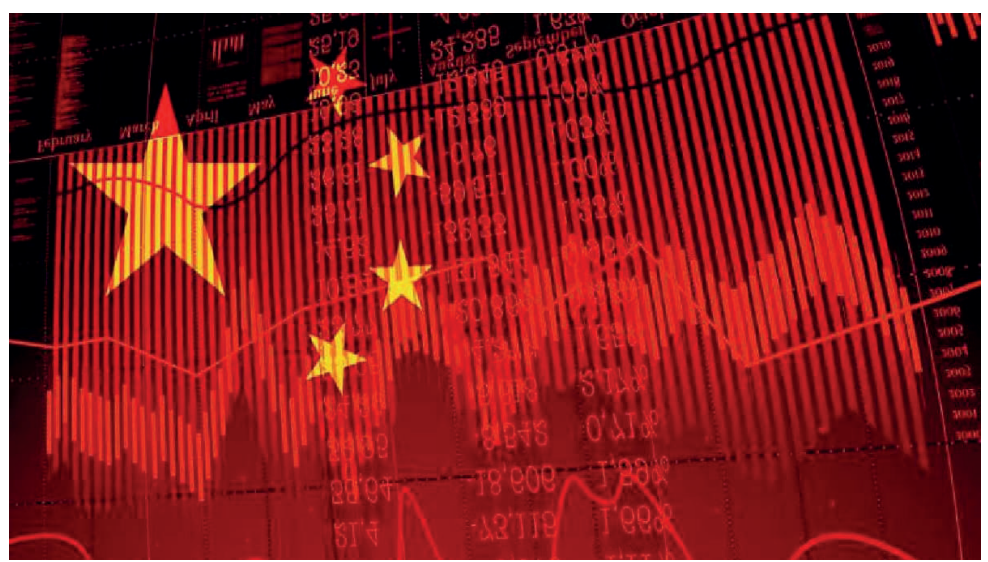

Pode-se dizer que o final do século XX foi marcado pela confluência de um caso de extremo sucesso de catching-up, iniciado nas últimas quatro décadas do referido século (Coreia do Sul), com o início e consolidação de um dos casos mais impressionantes de desenvolvimento robusto e continuado da história (República Popular da China), ainda em curso.

Todos os dados elencados a seguir demonstram ser uma experiência cujo sentido e estratégia de política micro e macroeconômica correspondem à estratégia defendida pelo novo-desenvolvimentismo. Seu crescimento econômico no período de 1980 e 2017 foi excepcional: a média de crescimento do PIB real no período foi de 9,2\% ao ano. Portanto, há mais de quatro décadas o país cresce, acima da média internacional, de forma quase ininterrupta (gráfico 7). 
Gráfico 7 - Crescimento do PIB real (\% a.a.) - China, 1960-2017

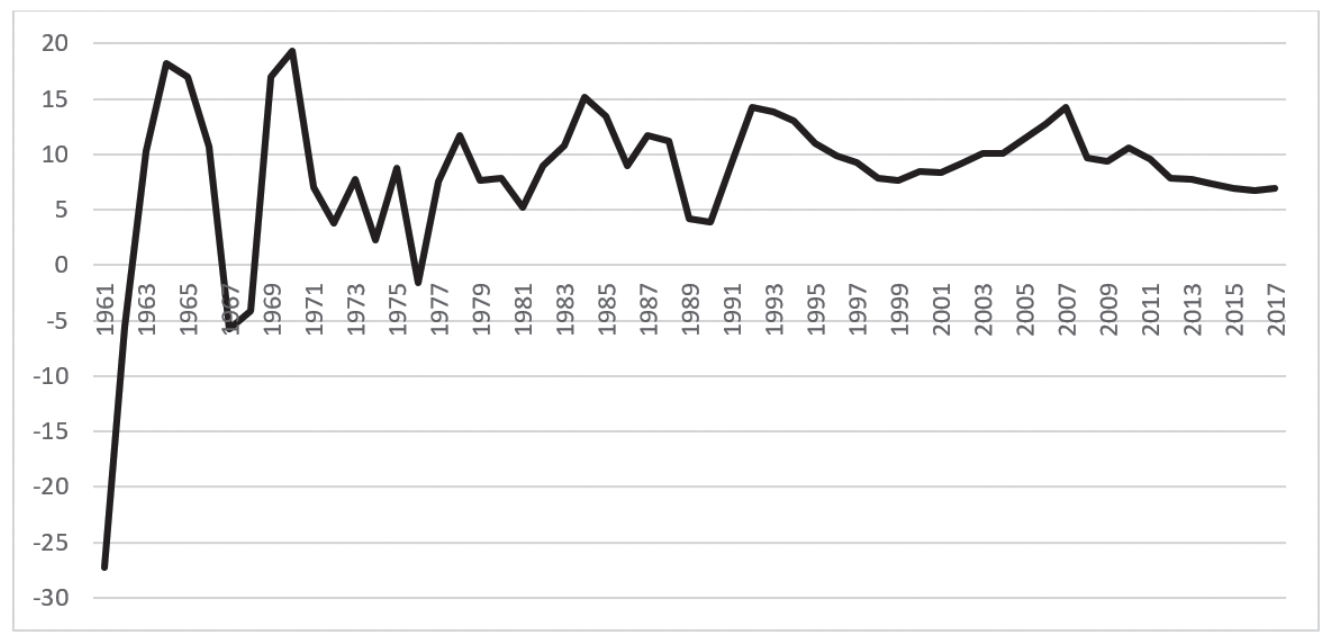

Fonte: World Bank.

A taxa média de crescimento do PIB per capita da China por mais de 35 anos, por sua vez, alcançou a média de cerca de $9 \%$ a.a., sendo que a renda per capita (por paridade de poder de compra) passou de apenas US\$250 dólares em I980 para US\$ 8.827 em 20I8, isto é, cresceu 36 vezes! Esse processo foi acompanhado de uma elevada taxa de investimento, com média de 36,9\% do PIB em I982-20II, e acima de $40 \%$ a partir de 2004 até a atualidade (gráfico 8).

Gráfico 8 - Formação bruta de capital fixo/PIB (\%) — China, 1960-2017

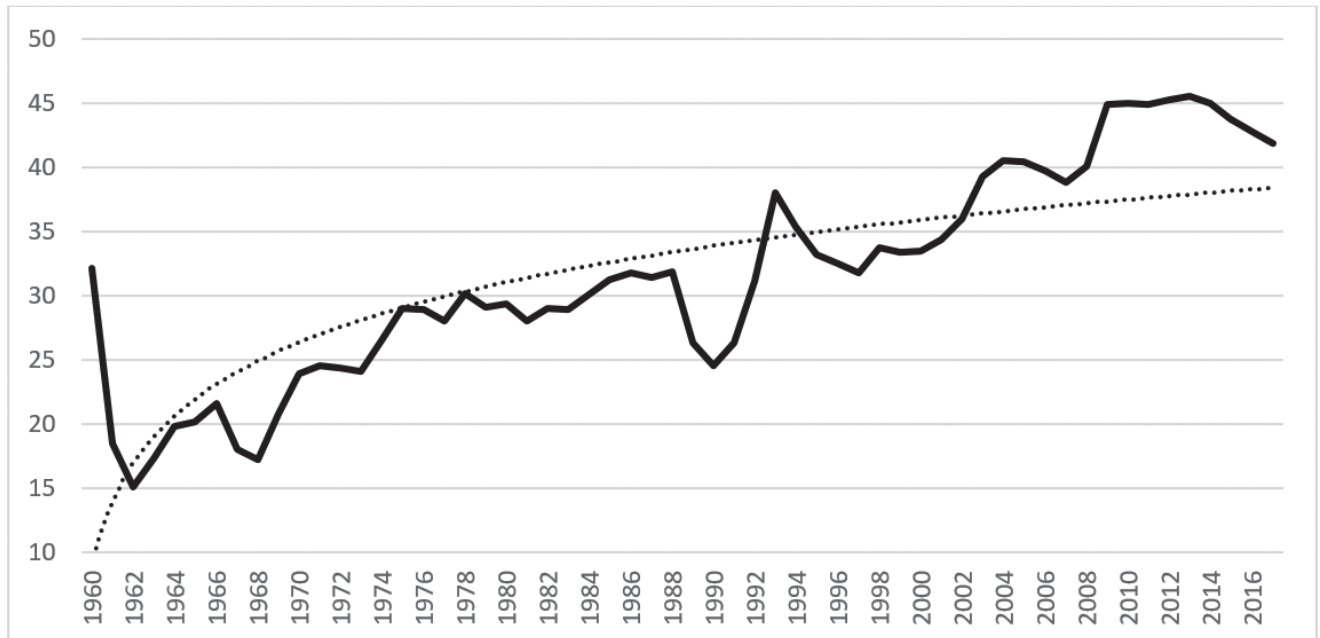

Fonte: World Bank. 


\section{Desde 2013, a China é o país}

de maior volume de comércio

exterior no mundo, desempenho

que tem provocado fortes efeitos

sobre praticamente todas as

economias nacionais, tornando-se

também grande exportadora de

capitais via investimentos diretos

no exterior

Desde 2013, a China é o país de maior volume de comércio exterior no mundo, desempenho que tem provocado fortes efeitos sobre praticamente todas as economias nacionais, tornando-se também grande exportadora de capitais via investimentos diretos no exterior (que aumentaram de US\$ 800 milhões em I990 para US\$ IOI,9 bilhões em 20I7). Como receptora de capitais externos, os investimentos diretos estrangeiros (IDEs) no país passaram de US\$ I,4 bilhão em I984 para US\$ I68,2 bilhões em 20I7. Enquanto até I99I os investimentos diretos na China eram voltados exclusivamente para os setores exportadores, com elevada concentração em Cantão, a partir daquele ano uma parcela crescente de IDE sob a forma de joint-ventures foi direcionada para a construção e ampliação de capacidade produtiva voltada ao mercado interno Não se conclua desses dados, porém, que a China cresceu com base na política de crescimento com endividamento externo. Entre 1980 e 2018 a China só apresentou déficit em conta-corrente (usou poupança externa) em três anos. Conforme defende o novo-desenvolvimentismo, a China não cometeu o erro de tentar crescimento com poupança externa e, assim, evitou que sua taxa de câmbio se apreciasse e suas empresas perdessem competitividade.

O peso da influência internacional do país e a percepção de uma combinação entre um modelo export-led (exportações acima de 30\% do PIB; ver gráfico 9) e o desenvolvimentismo podem ser notados na evolução da pauta comercial, que reflete o crescente grau de complexidade de sua indústria ${ }^{8}$. Em 1978, as exportações foram da ordem de US\$ 9,75 bilhões, passando em 2017 para US\$ 2,42 trilhões. A China teve déficits comerciais até 1989 , em função do maior crescimento das importações (alimentos, bens de capital etc.) vis-à-vis às exportações, sendo que estas, favorecidas pela desvalorização cambial, passaram a crescer fortemente a partir de 1995, acompa-

8 A pauta de exportações passou a ter um crescente peso de produtos manufaturados de maior valor agregado, como produtos eletrônicos e maquinários: segundo dados do Observatório da Complexidade Econômica, em 1997, o valor das exportações de produtos eletrônicos saiu de US\$19,4 bilhões em 1991 para US\$ 83,8 bilhões em 1997 e US\$ 174 bilhões em 2002, alcançando US\$ 718 bilhões em 2014. As exportações no setor de maquinários totalizaram US\$18,7 bilhões em 1997, mais que decuplicando em dez anos: US\$215bilhões em 2008 e US\$ 318 bilhões em 2014. 
nhadas pelo crescimento (um pouco abaixo) das importações, estas sujeitas a tarifas alfandegárias e não alfandegárias e a um câmbio desvalorizado, estimulando um processo vigoroso de substituição de importações e de forte empuxo das exportações.

\section{Gráfico 9 - Relação exportações/PIB (\%) - China, 1960-2017}

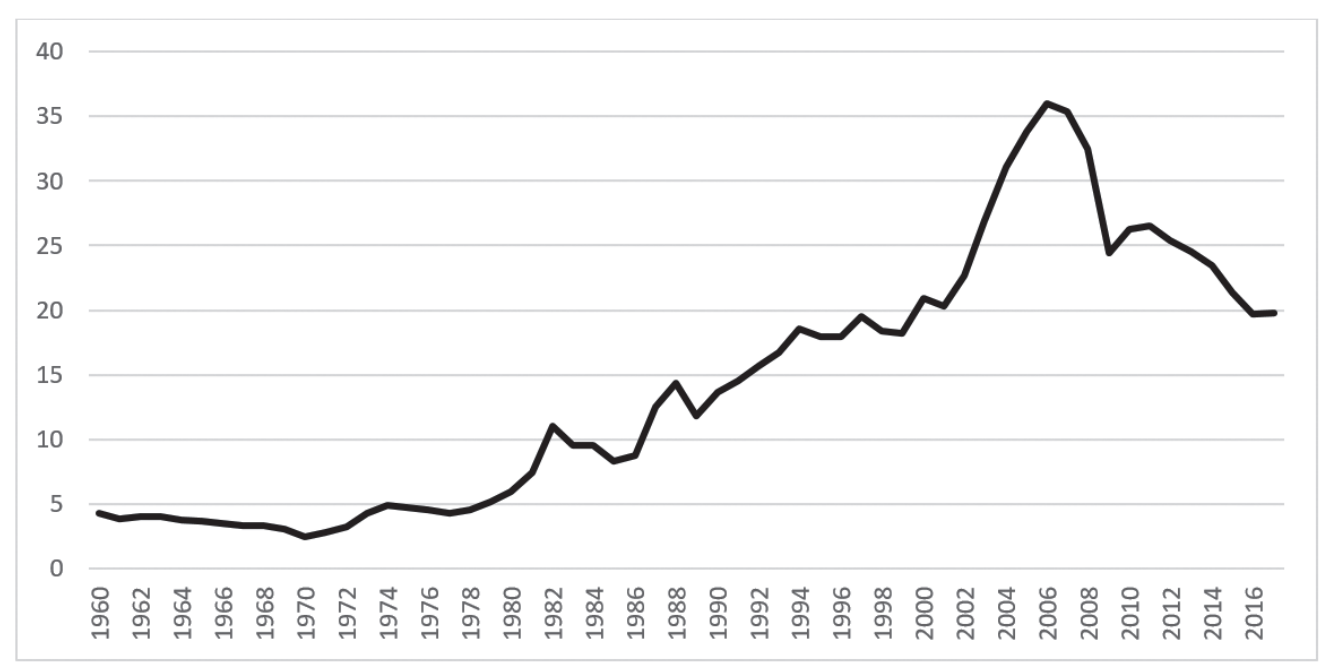

Fonte: World Bank.

As reservas cambiais, por sua vez, não obstante os grandes investimentos da China no exterior, saltaram de US\$ I,6 bilhão em 1978 para US\$ 3,09 trilhões em março de 2019, impulso propiciado pelo desempenho comercial e pelo afluxo de IDEs, sendo de longe as maiores do mundo. O fato de as exportações, desde o início da década de I990, terem ultrapassado as importações e a relação entre ambas obedecer a uma verdadeira "linha de proximidade" demonstra que a administração do balanço de pagamentos é um elemento fundamental de sua estratégia de desenvolvimento. Os dados sobre os juros reais e a inflação corroboram a relação entre essas variáveis em um país em catching-up: os juros reais, reagindo ao aumento da oferta de moeda e refletindo a estratégia de mudança do drive da economia do investimento ao consumo, reduzem-se de 7,2\% a.a. em média em 1997-I999 para 2,I\% a.a. em 2000-20I8. A inflação, medida pelo índice de preços ao consumidor, após o repique em I993-1995, com taxa média de I8,6\% a.a., vem se mantendo em patamares baixos desde o final da década de 1990, com média de I,9\% em 1997-2017 . A combinação entre taxa de câmbio estável, gradual liberalização comercial, crescimento da produtividade do trabalho e forte aumento na capacidade produtiva exerceu forte pressão baixista sobre a inflação a partir de 1997.

Houve, desde a década de I990, dois grandes movimentos de intervenção estatal sobre a economia chinesa. O primeiro grande registro se deu com o lançamento do Programa de Desenvolvimento do Grande Oeste, no ano de I999, e que rapidamente se converteu na maior transferência territorial de renda do mundo moderno

9 Dados extraídos do World Bank Data. 
(JABBOUR, 2006). Esse programa lançou o primeiro grande passo no sentido da unificação do território econômico da China, de forma semelhante ao ocorrido nos EUA na segunda metade do século XIX (OLIVEIRA, 2003). Tratou-se, também, de uma resposta aos impactos da crise financeira asiática de I997-I998 sobre a economia e o nível de emprego.

O segundo grande movimento de "intervenção em massa" do Estado na economia foi de caráter macroeconômico. Ocorreu como resposta à crise internacional iniciada em 2008. Naquele mesmo ano, no dia 5 de novembro, o Conselho de Estado da China anunciou ao mundo um vigoroso pacote de estímulos à economia, da ordem de US\$ 600 bilhões - à época, correspondente a I2,6\% do PIB. Uma verdadeira intervenção em massa do Estado na economia, diga-se de passagem. Em apenas alguns anos o país estaria cortado por novos milhares de quilômetros de linhas de trens de alta velocidade, metrôs e estradas ${ }^{10}$.

Ao lado da construção de institucionalidades, também as diferentes dinâmicas de acumulação embutiam novas políticas econômicas e industriais encetadas pelo Estado. A cada ciclo de inovações institucionais ${ }^{11}$, verificamos um aumento qualitativo do papel do Estado ao lado da elevação quantitativa do mercado/setor privado. Nesse sentido, políticas de "socialização do investimento" e seus mecanismos seriam a expressão máxima de um processo de construção de instituições capazes de refletir, ao longo do tempo, a estratégia do país.

A solução da "grande questão" (a relação entre Estado e mercado/setor privado) e a forma pela qual a China se preparou para os dois grandes movimentos de intervenção estatal aludidos acima foram acompanhadas pela introdução de mecanismos que dão contorno "novo-desenvolvimentista" à política econômica desde os primeiros anos da década de I990: I) reforma fiscal, revertendo a tendência anterior de descentralização e inaugurando um processo de construção de condições fiscais que permitiram a implementação posterior de políticas anticíclicas na China; 2) instituição de mecanismos de controle de fluxo de capitais, entendidos como necessários para controlar a taxa de câmbio ${ }^{12}$; 3) unificação da taxa de câmbio, que passou por uma maxidesvalorização em I984-I986 (gráfico Io).

A experiência chinesa demonstra o quão fundamental é o lugar da taxa de câmbio e do superávit em conta-corrente ao processo de desenvolvimento, dando validade teórica à abordagem novo-desenvolvimentista. Seu comportamento é sugestivo sobre os ciclos de mudanças institucionais pelas quais tem passado a economia chinesa desde o início das reformas econômicas. Foi contínua a tendência de desvalorizações

10 Cabe destacar que: 1) a relação investimento/PIB chegou à impressionante marca de 47,6\% em 2011, configurando capacidade produtiva instalada pronta a responder não somente a desafios internos, mas também externos, como o proposto pela configuração da Nova Rota da Seda (terrestre e marítima), lançada pelo presidente chinês Xi Jinping em setembro de 2013; 2) dados do National Bureau of Statistics of China (NBSC) mostram que a malha ferroviária chinesa saltou, entre 2009 e 2015, de 86 mil para 121 mil quilômetros de extensão.

11 Sobre os ciclos de inovações institucionais e sua ocorrência na China, ver Jabbour e Paula (2018).

12 Os objetivos desses controles se alteraram ao longo do tempo, mas, de maneira geral, visaram: 
do yuan desde I98I, até a maxidesvalorização de I994, ocorrida pari passu com um forte ajuste fiscal interno. Uma taxa fixa (US\$ I = 8,3 RMB) vigorou entre i995 e 2006. A partir de 2006, um regime cambial semifixo foi implantado. Desde 2015 o Banco Popular da China (BPC) tem intervindo no mercado cambial, depreciando o yuan de forma controlada. O gráfico Io mostra o comportamento da taxa de câmbio real na China em I980-20I7, período em que se pode observar uma tendência clara e gradual de forte depreciação no câmbio real entre I980 e I994, mantendo-se mais ou menos estável desde então (mas em níveis considerados subvalorizados) e passando a ter uma tendência à apreciação real (e gradual) até meados da década de 20I0, quando passou a se depreciar.

Gráfico 10 - Taxa de câmbio real efetiva — China, 1980-2017

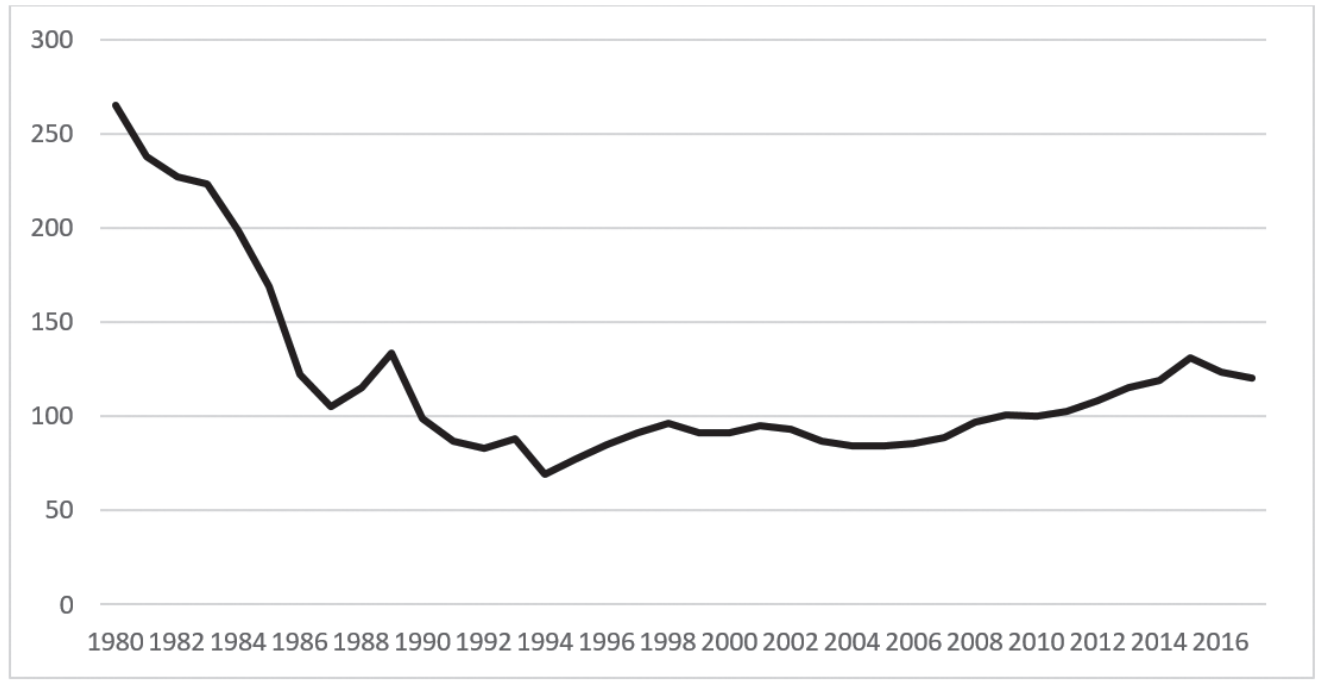

Fonte: Federal Reserve Economic Data.

O ciclo de inovação institucional dos anos 1990 abriu as portas a uma dinâmica de crescimento caracterizada pela "combinação de duas dinâmicas": uma dinâmica de export-led e outra de investment-led ${ }^{13}$. Essa combinação foi articulada por uma política industrial que determinou, e relacionou, a elevação da capacidade produtiva atrelada à expansão dos investimentos estrangeiros diretos, que saem, segundo dados do Banco Mundial, de US\$ 4,3 bilhões em I99I para US\$44,3 bilhões em I997. No início da década de 2000 um novo salto de qualidade é percebido na economia chinesa, com a amplia-

1) ajudar a canalizar a poupança externa para a utilização desejada; 2) manter a política monetária independente da influência do ambiente internacional; 3) evitar que empresas e instituições financeiras assumissem um risco externo excessivo; 4) manter em equilíbrio o balanço de pagamentos e a estabilidade da taxa de câmbio; 5) isolar a economia dos efeitos de crises financeiras internacionais (ZHAO, 2005 p. 8).

13 A relação entre exportações e PIB passa de 7,5\% em 1980 para 10,5\% em 1986 e 17,5\% em 1991, e alcança 20,4\% em 1995, 26,5\% em 2003 e 35,7\% em 2006, passando a cair desde então até chegar a $22,6 \%$ em 2015. A taxa de investimentos, como visto, passa por um forte processo de aceleração a partir do final da década de 1990. 
ção da política de substituição de importações, agora nos novos setores ligados à indústria mecânica pesada (trens de alta velocidade, por exemplo) ${ }^{14}$. Amplas políticas industriais direcionadas aos setores de ponta da economia desde então têm sido elaboradas e implementadas, e, combinadas com uma política cambial ativa, blindaram o país contra o risco de se tornar mais uma maquiladora de tipo mexicano, rompendo a fronteira prebischiana da sua antiga condição periférica para adentrar o centro do sistema ${ }^{15}$. O catching-up chinês hoje tomou a forma de um grande plano chamado "Made in China 2025".

É sugestiva a relação entre o forte ajuste fiscal de I994 e a criação de um ambiente propício ao lançamento de um grande pacote fiscal com vistas ao enfrentamento da crise asiática de 1997 pela via do fortalecimento da demanda doméstica. Essa correta política econômica não se restringiu à promoção de boas condições fiscais, inflação controlada, baixas taxas de juros convidativas à expansão da capacidade produtiva e acesso das empresas nacionais à demanda doméstica (proporcionada pela instituição de um câmbio fixo e depreciado). Um salto de qualidade da ação estatal sobre a economia também fora forjado ao longo das reformas econômicas: a formação de um sistema financeiro público voltado ao investimento de longo prazo.

A evolução institucional do sistema financeiro acompanhou as exigências do processo de reformas econômicas, e até mesmo antecipou-se a elas, incluindo a superação do alto grau de repressão financeira. Entre 1978 e I984 o Banco Popular da China tornou-se o responsável pela regulação do sistema financeiro, regendo comissões, como a de Regulação Bancária da China (CBRC), a de Regulação dos Valores Mobiliários da China (CSRC) e a de Regulação de Seguros da China (CIRC). Ao mesmo tempo, quatro grandes bancos estatais foram se formando ao longo do tempo ("Big Four") ${ }^{16}$, além da emergência de um grande número de bancos nacionais e regionais de variados tipos de controle de capital, atendendo às exigências da agricultura, construção urbana, infraestrutura e financiamento de exportações e importações, e de ter havido um gradual desenvolvimento do mercado de capitais na China.

Fica evidente que a China criou um sistema de financiamento da atividade produtiva, voltado para a transformação estrutural da economia e que se revelou bastante funcional ao processo de desenvolvimento do país. O gráfico II mostra que a relação entre crédito doméstico às empresas e PIB (inclui empresas mistas e estatais, além das privadas propriamente ditas) esteve na ordem de 50\%-70\% em I977-1985 e cresceu fortemente desde então, acompanhando o acelerado processo de crescimento econômico do país e alcançando mais de IOO\% do PIB já em 1998 e mais de $130 \%$

14 Ao antecipar a grande demanda doméstica e garantir acordos de transferência de tecnologia de países detentores de tecnologia de ponta nesse setor, em contratos que remontam à segunda metade da década de 1990, a China deixou de ser um país importador de tecnologia em trens de alta velocidade até 2004 para se tornar líder no mercado mundial a partir de 2011.

15 Sobre as diferentes políticas industriais executadas pelo governo chinês desde o início dos anos 2000, ver Gabriele (2010) e Lo e Wu (2014).

16 São eles: Industrial and Commercial Bank of China, Construction Bank of China, Agricultural Bank of China e Bank of China. Além deles, há três bancos de desenvolvimento públicos: China Development Bank, Agricultural Bank of China e Export-Import Bank of China, voltados ao apoio à agricultura, infraestrutura e comércio exterior. 
a partir de 2012. De fato, o sistema financeiro chinês e sua forte expansão creditícia permitiram o financiamento do investimento em setores, empresas, regiões e infraestrutura selecionados, "a coluna vertebral do dinamismo quantitativo e qualitativo do investimento" (CINTRA; SILVA FILHO, 20I5, p. 448).

\section{Gráfico 11 - Crédito doméstico ao setor privado - China, 1977-2016}

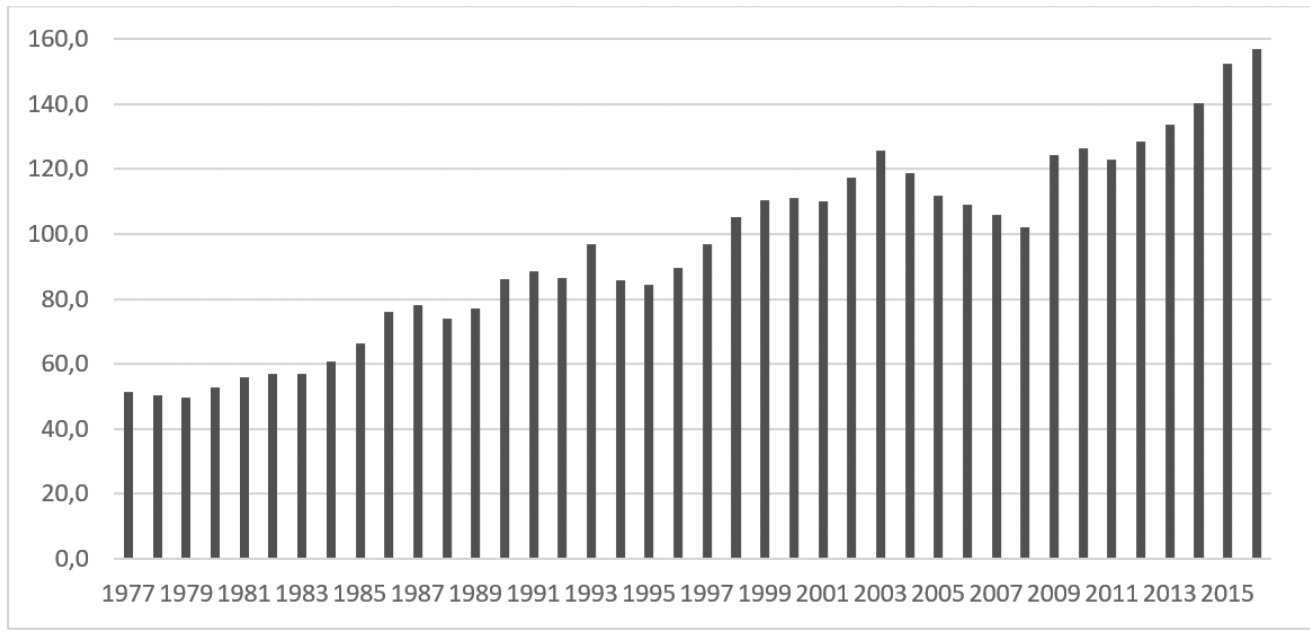

Fonte: World Bank.

A administração do balanço de pagamentos é outra característica interessante do processo chinês. Com apoio nos dados do gráfico I2, é possível inferir, inclusive, uma relação direta entre a desvalorização da taxa de câmbio em 1994 e o comportamento do balanço de pagamentos.

\section{Gráfico I2 - Balanço de pagamentos (\% do PIB) - China, 1982-20I8}

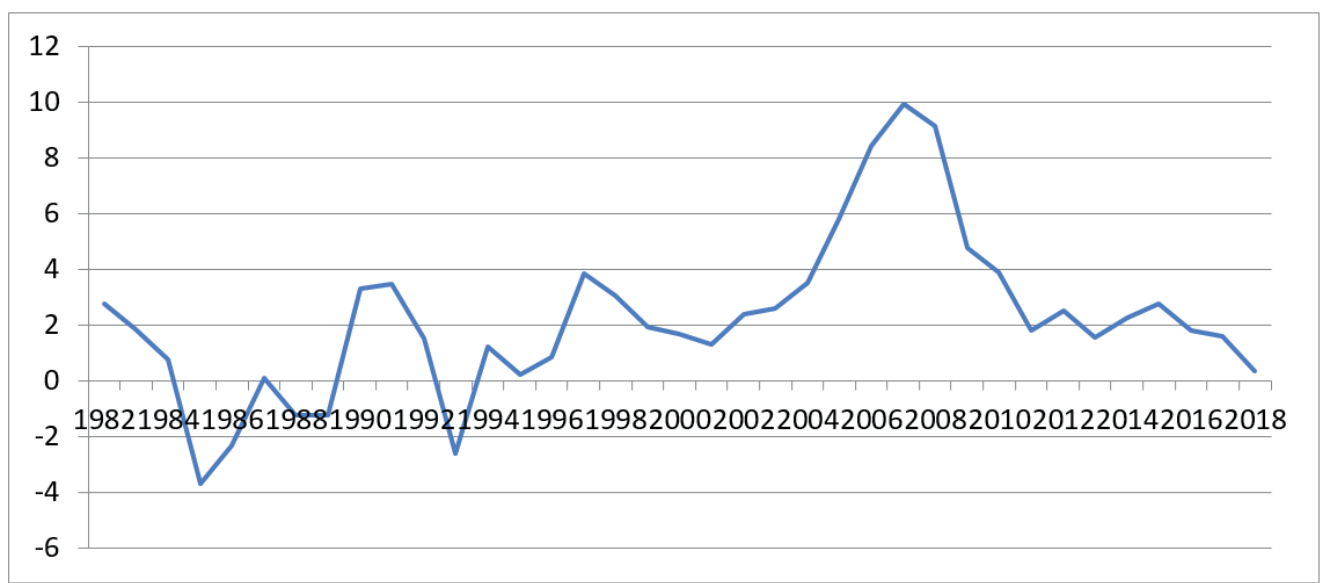

Fonte: World Bank. 
Em suma, a estratégia chinesa de desenvolvimento pode ser caracterizada pela combinação dos seguintes elementos: I) a ocorrência de ciclos de inovações institucionais que, ao reafirmar estrategicamente o papel do Estado, consequentemente permitem soluções de continuidade ao processo de desenvolvimento; 2) uma política cambial associada à política de superávits em conta-corrente e ao controle do fluxo de capitais para manter a taxa de câmbio competitiva e, assim, garantir: a) acesso à demanda interna e externa pelas empresas nacionais; b) correta administração do balanço de pagamentos; c) formação de um policy space (via formação das maiores reservas cambiais do mundo); 3) política de juros baixos, desestimulando os influxos de capitais e estimulando, junto com o aumento dos salários reais, o papel do consumo no conjunto da demanda; 4) combinação de uma correta estratégia de adensamento produtivo nas exportações com altas taxas internas de investimentos; 5) importante controle estatal sobre a grande propriedade estatal nos setores estratégicos e no sistema financeiro.

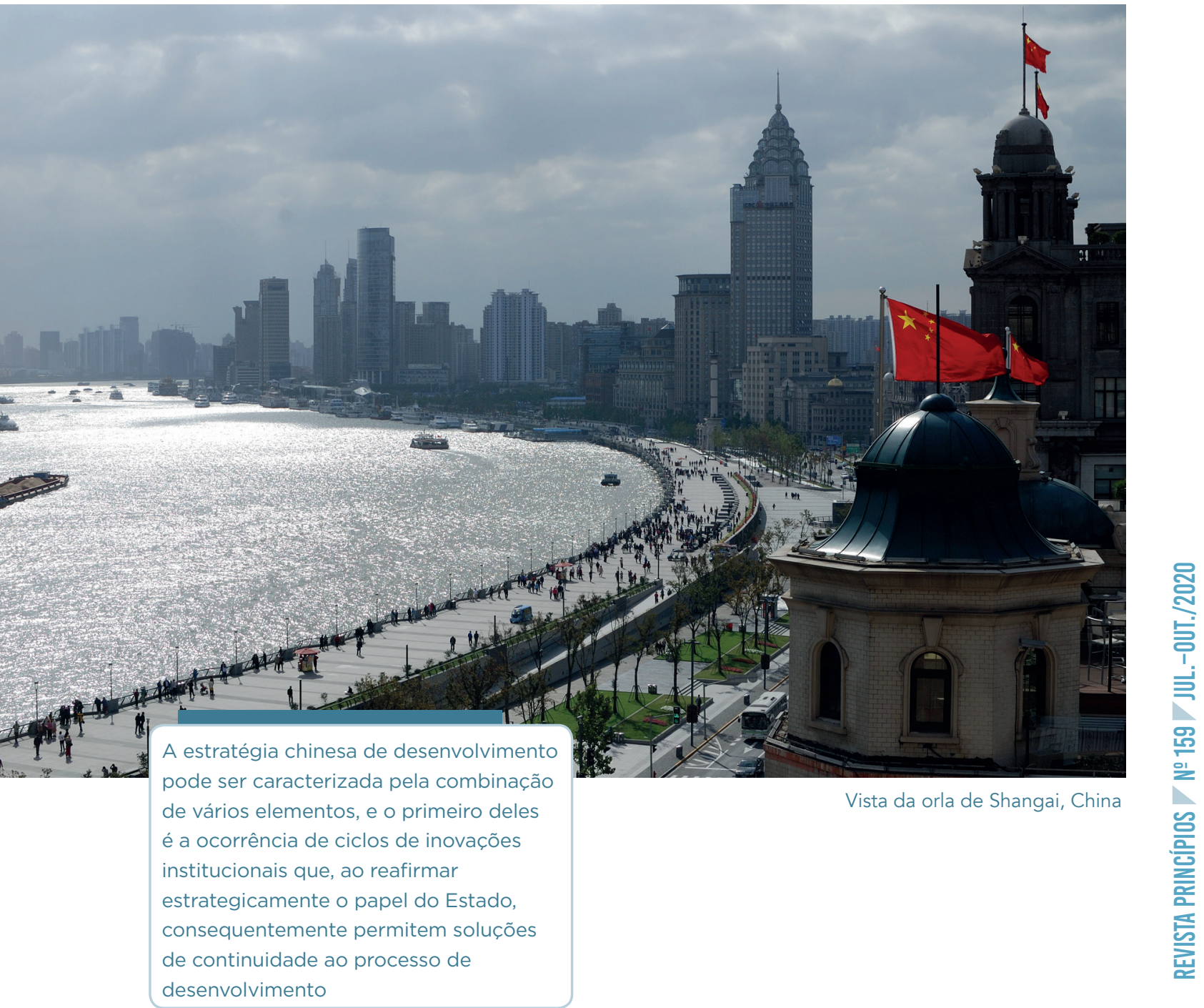




\section{CONSIDERAÇ̃̃ES FINAIS}

Voltamos à questão fundamental deste artigo: em que medida o processo de catching-up na Coreia do Sul e na China pode ser entendido como a aplicação de uma estratégia novo-desenvolvimentista?. O novo-desenvolvimentismo é um arcabouço teórico que se baseia principalmente na experiência bem-sucedida dos países do Leste Asiático. Neste artigo verificamos mais especificamente essa hipótese, e ela foi confirmada. Foi possível detectar uma relação de complementaridade entre Estado e mercado como processo dinâmico que se altera ao longo do tempo. Além de uma política industrial estratégica, verificamos nas fases de crescimento acelerado que: I) as duas contas macroeconômicas foram mantidas equilibradas; 2 ) a conta-corrente foi geralmente mantida superavitária (se o país tem doença holandesa); 3) as entradas e saídas de capitais não foram deixadas ao sabor do mercado (que é incapaz de mantê-las equilibradas), mas controladas; 4) a taxa de juros paga pelo Estado foi mantida abaixo da taxa de crescimento da economia: não foi deixada ao sabor do mercado, mas controlada de forma a manter a dívida pública em nível razoável; 5) o financiamento do investimento foi assegurado por bancos públicos; 6) os cinco preços básicos (câmbio, taxa de juros, salário, inflação e lucro) foram firmemente administrados.

Destacamos as dinâmicas de desenvolvimento da Coreia do Sul e da China colocando acento nas distintas estratégias de caráter export-led de suas estratégias de crescimento e no peso das políticas industriais, dos superávits em conta-corrente, taxas de câmbio competitivas, crescimento gradual dos salários, altas taxas de investimentos e estímulos às exportações. Procuramos neste artigo mostrar que boas políticas industriais não prescindem da boa administração dos preços macroeconômicos e da definição de uma estratégia nacional de desenvolvimento. E, mais amplamente, argumentamos que o regime de política econômica nesses dois países não se limitou a incorporar as ideias do desenvolvimentismo clássico, que são essencialmente microeconômicas, mas incorporou também a visão de longo prazo do novo-desenvolvimentismo e sua macroeconomia do desenvolvimento.

* Professor emérito da Fundação Getúlio Vargas (FGV-SP).

** Professor da Faculdade de Ciências Econômicas da Universidade do Estado do Rio de Janeiro (FCE-Uerj) e de seu Programa de Pós-Graduação em Ciências Econômicas (PPGCE-Uerj).

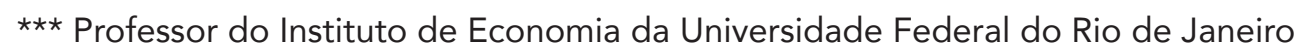
(IE-UFRJ), coordenador do Grupo de Estudos de Economia e Política (GEEP) do Instituto de Estudos Sociais e Políticos (lesp) da Uerj e pesquisador do Conselho Nacional de Desenvolvimento Científico e Tecnológico (CNPq). 
ALDRIGHI, D. M. Financiamento e desenvolvimento econômico: teorias e a experiência coreana. São Paulo: Fipe-USP, 1997.

AMSDEN, A. A ascensão do "resto": os desafios ao Ocidente de economias com industrialização tardia. São Paulo: Editora Unesp, 2004.

Asia's next giant: South Korea and late industrialization. Nova York: Oxford University Press, 1989.

BRESSER-PEREIRA, L. C. From old to new developmentalism in Latin America. In:

BRESSER-PEREIRA, L. C.; OREIRO, J. L.; MARCONI, N. Developmental macroeconomics as a growth strategy. Abington: Routledge, 2015.

BURLAMAQUI, L. Finance, development and the Chinese entrepreneurial state: a Schumpeter-Keynes-Minsky approach. Brazilian Journal of Political Economy, São Paulo, v. 35 , n. 4, p. 728-744, 2015.

CHANG, H. J. The political economy of industrial policy in Korea. Cambridge Journal of Economics, Oxford, v. 17, p. 131-157, 1993.

Kicking away the ladder: development strategy in historical perspective. Londres: Anthem Press, 2002.

CINTRA, M.; SILVA FILHO, E. O sistema financeiro chinês: a grande muralha. In:

PINTO, E. (Org.). China em transformação: dimensões econômicas e geopolíticas do desenvolvimento. Brasília: Ipea, 2015.

EVANS, P. O Estado como problema e solução. Lua Nova, São Paulo, n. 28-29, p. 107-157, abr. 1993.

FONSECA, P. C. D. Desenvolvimentismo: a construção do conceito. Texto para Discussão, n. 2.103. Brasília: Ipea, jul. 2015. Disponível em: <http://repositorio.ipea.gov.br/ bitstream/11058/4580/1/td 2103.pdf>. Acesso em: 17 jun. 2020.

GALA, P. Dois padrões de política cambial: América Latina e Sudeste Asiático. Economia e Sociedade, Campinas, v. 16, n.1, p. 65-91, 2007.

GABRIELE, A. The role of the state in China's industrial development: a reassessment.

Comparative Economic Studies, London, v. 52, n. 3, p. 325-350, 2010.

GERSCHENKRON, A. Economic backwardness in historical perspective: a book of essays. Nova York: Frederick A. Praeger Publishers, 1962.

GUARINI, G.; RABELLOTTI, R. Is Korea catching up?: an analysis of the labour productivity growth in South Korea. Oxford Development Studies, Oxford, v. 34, n. 3, p. 323-339, 2006.

GUIMARÃES, A. Q. Estado e economia na Coreia do Sul: do estado desenvolvimentista à crise asiática e à recuperação posterior. Revista de Economia Política, São Paulo, v. 30, n. 1, p. 45-62, 2010.

GUZMAN, M.; OCAMPO, J. A.; STIGLITZ, J. Real exchange rate policies for economic development. World Development, v. 110, p. 51-62, 2018. 
JABBOUR, E. China: infraestruturas e crescimento econômico. São Paulo: Anita Garibaldi, 2006.

; DANTAS, A. The political economy of reforms and the present Chinese transition. Brazilian Journal of Political Economy, São Paulo, v. 37, n. 4, p. 789-807, 2017.

JABBOUR, E.; PAULA, L. F. A China e a "socialização do investimento": uma abordagem Keynes-Gerschenkron-Rangel-Hirschman. Revista de Economia Contemporânea, Rio de Janeiro, v. 22, n. 1, p. 1-23, 2018.

JOHNSON, C. MITI and the Japanese miracle: the growth of industrial policy (1925-1975). Stanford: Stanford University Press, 1982.

KEYNES, J. M. The "ex ante" theory of the rate of interest. Economic Journal, Oxford, v. 47, n. 188, p. 663-669, dez. 1937.

KIM, S. The Korean miracle (1962-1980) revisited: myths and realities in strategy and development. Working paper 166, South Bend Kellogg Institute. 1991.

LO, D.; WU, M. The state and industrial policy in Chinese economic development. In: SALAZAR-XIRINACHS, J. M.; NÜBLER, I.; KOZUL-WRIGHT, R. (Ed.). Transforming economies: making industrial policy work for growth, jobs and development. Genebra: International Labour Office, 2014.

MARCONI, N. The industrial equilibrium exchange rate in Brazil: an estimation. Brazilian Journal of Political Economy, São Paulo, v. 32, n. 4, p. 656-669, 2012.

MEDEIROS, C. Globalização e a inserção internacional diferenciada da Ásia e da América Latina. In: TAVARES, M. C.; FIORI, J. L. Poder e dinheiro: uma economia política da globalização. Petrópolis: Vozes, 1997.

Padrões de investimento, mudança institucional e transformação estrutural na economia chinesa. In: BIELSCHOWSKY, R. (Org.). Padrões de desenvolvimento econômico (1950-2008): América Latina, Ásia e Rússia. Brasília: CGEE, 2013.

Raízes estruturais da crise financeira asiática e o enquadramento da Coreia.

Economia e Sociedade, Campinas, v. 7, n. 2, p. 151-172, 1998.

MEDEIROS, C. A.; CINTRA, M. R. V. P. Economia e política do desenvolvimento recente da China. Revista de Economia Política, São Paulo, v. 19, n. 3, p. 92-112, 1999.

NAM, C. The role of trade and exchange rate policy in Korea's growth. In: ITO, T.; KRUEGER, A. (Ed.). Growth theories in light of the East Asian experience. Chicago: NBER-EASE, 1995. Disponível em: <www.nber.org/books/ito 95-2>. Acesso em: 17 jun. 2020.

NAUGHTON, B. Growing out of the plan: Chinese economic reform (1978-1993).

Cambridge: Cambridge University Press, 1996.

Is China socialist?. Journal of Economic Perspectives, Nashville (USA), v. 31, n. 1, p. 3-24, 2017. 
The Chinese economy: transitions and growth. Londres: MIT Press, 2007.

OCAMPO, J. A.; ROS, J. (Ed.). The Oxford handbook of Latin American economics. Oxford: Oxford University Press, 2011.

Globalization and competition: why some emergent countries succeed while others fall behind. Cambridge: Cambridge University Press, 2009.

Resumo do novo-desenvolvimentismo em 2015. In: OREIRO, J.; PAULA, L. F; MARCONI, N. (Org.). A teoria econômica na obra de Bresser-Pereira. Santa Maria: Editora UFSM, 2015.

; GALA, P. Foreign savings, insufficiency of demand, and low growth, Journal of Post Keynesian Economics, London, v. 30, n. 3, 2008, p. 315-334. Disponível em: <http:// dx.doi.org/10.2753/PKE0160-3477300301>. Acesso em: 17 jun. 2020.

OLIVEIRA, A. P. O salto qualitativo de uma economia continental. Política Externa, São Paulo, v. 11, n. 4, p. 6-13, 2003.

OREIRO, J. Novo-desenvolvimentismo, crescimento econômico e regimes de política macroeconômica. Estudos Avançados, São Paulo, v. 26, n. 75, p. 29-40, 2012.

PALMA, G. Flying geese and waddling ducks: the different capabilities of East Asia and Latin America to "demand-adapt" and "supply-upgrade" their export productive capacity. In: CIMOLI, M., DOSI, G.; STIGLITZ, J. (Ed.). The political economy of capabilities accumulation: the past and future of policies for industrial development. Oxford: Oxford University Press, 2009.

PAULA, L. F. Financiamento, crescimento econômico e funcionalidade do sistema financeiro: uma abordagem pós-keynesiana. Estudos Econômicos, São Paulo, v. 43, n. 2, p. 363-396, 2013.

- Macroeconomia do desenvolvimento de Bresser-Pereira: para além da ortodoxia e do keynesianismo vulgar. In: OREIRO, J.; PAULA, L. F.; MARCONI, N. (Org.). A teoria econômica na obra de Bresser-Pereira. Santa Maria: Editora UFSM, 2015.

RODRIK, D. The real exchange rate and economic growth. Brookings Papers on Economic Activity, Washington (USA), v. 39, n. 2, p. 365-439, 2008.

RODRIGUEZ, O. O estruturalismo latino-americano. Rio de Janeiro: Civilização Brasileira, 2009.

STIGLITZ, J. Some lessons from the East Asian miracle. The World Bank Research Observer, Oxford, v. 11, n. 2, p. 151-177, 1996.

ZHAO, M. External liberalization and the evolution of China's exchange system: an empirical approach. World Bank China Office working paper n. 4. Washington, D.C.: World Bank, 2005. 